\title{
A note on concentrations of metals in cetaceans from southern Africa
}

\author{
JOHN HENRY
}

$5+A$ Creffield Road, Colchester, $\mathrm{CO} 33 \mathrm{HY}$, England

AND PETER BEST*

Mammal Research Institute, University of Pretoria, Pretoria, 0002 South Africa

Contacte-mail: pbest@samuseum.ac.za

\begin{abstract}
Concentrations of zinc, copper, cadmium, mercury and lead were measured by atomic absorption spectrophotometry in samples of the brain, kidney, Jiver and muscle tissue from 178 individuals of 323 different cetacean species (4 right whales - Eubalaena australis, 2 pygmy right whales Caperea marginata, 3 minke whales - Balaenoptera acutorostrata, 3 Bryde's whales - B. edeni, 1 humpback whale - Megaptera novaeangliae, 1 sperm whale - Physeter macrocephalus, 11 pygmy sperm whale - Kogia breviceps, 6 dwarf sperm whales - K. simus, 1 southern bottlenose whale - Hyperoodon planifrons, 1 Cuvier's beaked whale - Ziphius cavirostris, 9 Blainville's beaked whales - Mesoplodon densirostris, 5 strap-tooth whales - M. layardii, 2 True's beaked whales - M. mirus, 3 long-finned pilot whales - Globicephala melas, 30 Risso's dolphins Grampus griseus, 12 bottlenose dolphins - Tursiops truncatus, 5 striped dolphins - Stenella coeruleoalba, 1 pantropical spotted dolphin - S. attenuata, 1 hump-backed dolphin - Sousa chinensis, 21 dusky dolphins - Lagenorhynchus obscurus, 1 hourglass dolphin - L. cruciger, 12 Heaviside's dolphins - Cephalorhynchus heavisidii and 43 common dolphins - Delphinus delphis). All but the hourglass dolphin were strandings or animals taken incidental to fishing operations or under scientific permit in coastal waters of South Africa or Namibia. Highest concentrations of $\mathrm{Zn}$, $\mathrm{Cu}$ and $\mathrm{Hg}$ were generally found in the liver and of $\mathrm{Cd}$ in the kidney. Comparisons of animals pre-and post puberty indicated accumulation of hepatic mercury in the pygmy sperm whale, Risso's dolphin, dusky dolphin and common dolphin. Loss of a metal (zinc) after puberty was only shown in the common dolphin. No individual analyses exceeded proposed (human) tolerance limits for hepatic mercury and hepatic or renal cadmium.
\end{abstract}

KEYWORDS: SOUTH AFRICA; POLLUTION; METALS; RIGHT WHALE; PYGMY RIGHT WHALE: MINKE WHALE; BRYDE'S WHALE; HUMPBACK WHALE; SPERM WHALE; PYGMY SPERM WHALE; DWARF SPERM WHALE; SOUTHERN BOTTLENOSE WHALE; CUVIER'S BEAKED WHALE; BLAINVILLE'S BEAKED WHALE ; STRAP-TOOTHED WHALE; TRUE'S BEAKED WHALE; LONG-FINNED PILOT WHALE; RISSO'S DOLPHIN; BOTTLENOSE DOLPHIN; STRIPED DOLPHIN; SPOTTED DOLPHIN; HUMPBACK DOLPHIN; DUSKY DOLPHIN; HOURGLASS DOLPHIN; HEAVISIDE'S DOLPHIN; COMMON DOLPHIN.

\section{INTRODUCTION}

This note stems from a general survey of the incidence of metals in marine organisms in South African waters carried out between 1982 and 1990. Cetaceans were considered especially interesting because of their position at the top of the food chain and the consequent expectation that contaminant levels might be relatively high. However, legal and logistical constraints meant that access to material was mainly opportunistic depending on the natural

*Address for reprints/correspondence: c/o South African Museum, PO Box 61, Cape Town 8000, South Africa. 
occurrence of strandings and the accidental entanglements of individuals in fishing gear. As a consequence, sample sizes vary greatly among species, and for no one species were sufficient individuals analysed for a detailed examination of the effects of sex, age and locality on contaminant levels (Aguilar et al., 1999). Nevertheless, this represents the first such survey for cetaceans in the sub-region, and has value as a baseline study against which future developments might be measured.

Five metals have been analysed in this paper; zinc, copper, cadmium, mercury and lead. The first two are usually classified as essential metals and the remainder as non-essential metals (Bowles, 1999).

\section{MATERIALS AND METALS}

Samples for metal analysis were taken from 178 cetaceans of 23 species (Table 1 and Appendix Table 1). All but three animals were obtained between 1982 and 1990. Of the specimens, 127 were stranded on the coastline, 24 entangled in fishing gear and 5 collected at sea under special permit in the waters of South Africa or Namibia. An hourglass dolphin specimen was also collected at sea under special permit in the southwestern Atlantic, and one common dolphin was found unlabelled in the freezer.

Most samples of brain tissue $(n=170)$ were taken through the foramen magnum, and so probably consisted of cerebellum. Muscle tissue $(n=173)$ was removed from the core of one of the dorsal muscle fillets, liver tissue $(n=167)$ from the apex of one of the lobes and kidney tissue $(n=166)$ from the centre of one of the kidneys. All samples were placed in acid-washed polystyrene containers and kept frozen at $-20^{\circ} \mathrm{C}$ until analysis.

Individual cetaceans were assigned into relative age categories, as follows:

(1) calf - still suckling;

(2) juvenile - weaned but sexually immature;

(3) sub-adult - sexually mature but physically immature;

(4) adult - both sexually and physically mature.

Criteria for sexual maturity (and thus immaturity) in females included the presence of an active lactating mammary gland, a corpus luteum or corpus albicans in the ovaries or a foetus. Sexual maturity in males was determined from the size of the testes. An individual was judged physically mature if the epiphyses of the fourth or fifth anterior thoracic vertebrae were fused to their centra: otherwise they were adjudged to be physically immature.

In total, 21 calves, 67 juveniles, 55 sub-adults and 35 adults were sampled. To increase the sample size for analyses of trend in metal concentration with age, calves and juveniles have been combined as 'immature' and sub-adults and adults as 'mature'.

Analyses of metal concentrations were carried out by atomic adsorption spectrophotometry. For the analysis of copper, zinc, cadmium and lead, $2 \mathrm{~g}$ wet weight of tissue were added to $25 \mathrm{ml}$ of concentrated nitric acid and allowed to stand overnight. The resulting digest was gently evaporated almost to dryness. A further $25 \mathrm{ml}$ of a $4: 1$ mixture of concentrated nitric acid and perchloric acids was added to the residue of the first digestion and again slowly evaporated almost to dryness. The final residue was dissolved in $10 \%$ nitric acid. This solution was aspirated into a Varian Spectra 10 atomic absorption spectrophotometer (AAS) which was set up for each metal according to the instrument manufacturer's recommendations.

The analytical method used for mercury was that of Evans et al. (1986) in which wet tissue was treated with concentrated nitric acid and allowed to stand overnight. The acid was then slowly heated to a temperature of $125^{\circ} \mathrm{C}$ over a period of three hours and then reflexed for 


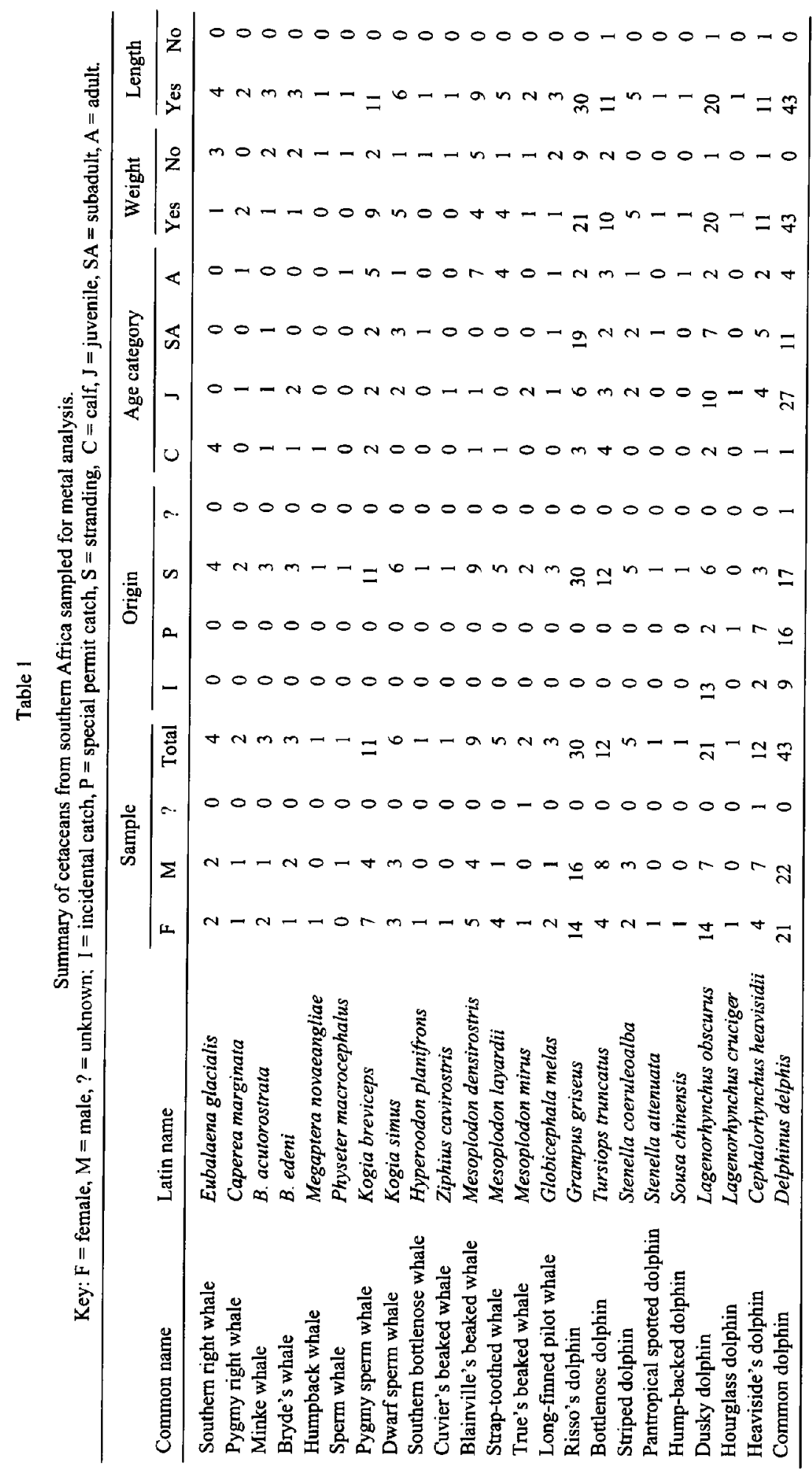


a further four hours. The final digest was diluted with water and analysed using a Varian vapour generation accessory (VGA-76) linked to the Varian Spectra 10 AAS and fed by a Varian PSC-55 sample changer. The reducing agent, $25 \% \mathrm{w} / \mathrm{v}$ stannous chloride in $20 \% \mathrm{w} / \mathrm{v}$ hydrochloric acid was added at a rate and under conditions only slightly modified from those recommended by Evans et al. (1986). The limit quantification LOQ, defined in Zak et al. (1983) as the concentration above which quantitative results can be obtained with a specified confidence, in this case $\pm 30 \%$ in the measured value at $99 \%$ confidence level, was calculated for copper as $0.1 \mu \mathrm{g} / \mathrm{g}$, zinc as $0.05 \mu \mathrm{g} / \mathrm{g}$, cadmium as $0.2 \mu \mathrm{g} / \mathrm{g}$, lead as $0.4 \mu \mathrm{g} / \mathrm{g}$, and mercury as $0.1 \mu \mathrm{g} / \mathrm{g}$.

All metal concentrations quoted are in $\mu \mathrm{g} / \mathrm{g}$ wet mass. Figures following \pm (and all error bars on the Figures) refer to one standard deviation of the mean.

A total of 2,354 analyses was carried out, 491 of brain, 655 of kidney, 644 of liver and 564 of muscle tissue (Table 2). Analyses for zinc, copper and mercury were similar in number (534, 656 and 577 respectively), whereas fewer analyses were completed for cadmium (355) and lead (132). Three lead analyses from brain tissue have been excluded from the results presented because they originated from animals killed by a gunshot to the head: lead concentrations recorded for these individuals $(25.9,95.2$ and $164 \mu \mathrm{g} / \mathrm{g})$ were $7-46$ times higher than the next highest concentration recorded for the brain.

Table 2

Numbers of analyses of each heavy metal carried out for each tissuc, in cetaceans from southern Africa.

\begin{tabular}{lcccccc}
\hline & \multicolumn{7}{c}{ Metal } \\
\cline { 2 - 7 } Tissue & Zinc & Copper & Cadmium & Mercury & Lead & Total \\
\hline Brain & 131 & 165 & 34 & 130 & 31 & 491 \\
Kidney & 163 & 164 & 142 & 147 & 39 & 655 \\
Liver & 168 & 165 & 134 & 151 & 26 & 644 \\
Muscle & 172 & 162 & 45 & 149 & 36 & 564 \\
Total & 634 & 656 & 355 & 577 & 132 & 2.354 \\
\hline
\end{tabular}

\section{RESULTS}

\section{Distribution between tissues}

Given the high individual variability in contaminant levels, only individuals in which all four tissues were analysed have been examined in order to determine the relative contaminant loads between tissues. The results for zinc, copper, cadmium and mercury are shown in Table 3.

The highest concentrations of zinc were found in the liver of $84.9 \%$ of the individuals for which all four tissues were examined. Some $13 \%$ had their highest concentration in the kidney, and very few ( 0.6 and $1.5 \%$ respectively) in the brain or muscle.

The liver was also the site of the highest concentrations of copper in most $(85.7 \%)$ individuals, followed by the kidney $(8.2 \%)$ and the brain $(6.1 \%)$. The two Kogia species formed an exception, in that the highest copper concentration most frequently occurred in the brain $(53.8 \%)$, followed by the liver $(46.2 \%)$.

Cadmium levels were highest in the kidney of $73.9 \%$ of individuals, followed by the liver $(21.7 \%)$ and muscle $(4.4 \%)$.

Mercury levels were highest in the liver of $85 \%$ of individuals, with relatively few animals (3.5, 4.2 and $6.7 \%$ respectively) having their highest levels in the kidney, brain or muscle. 
Table 3

Frequency with which the highest concentrations of heavy metals were found in the brain, kidney, liver or muscle of cetaceans off southern Africa.

\begin{tabular}{|c|c|c|c|c|c|c|c|c|}
\hline Tissue & Zinc & $\%$ & Copper & $\%$ & Cadmium & $\%$ & Mercury & $\%$ \\
\hline Brain & 1.0 & 0.6 & 9.0 & 6.1 & 0.0 & 0.0 & 5.25 & 4.8 \\
\hline Kidney & 21.0 & 13.0 & 12.0 & 8.2 & 17.0 & 73.9 & 3.75 & 3.5 \\
\hline Liver & 137.5 & 84.9 & 126.0 & 85.7 & 5.0 & 21.7 & 91.75 & 85.0 \\
\hline Muscle & 2.5 & 1.5 & 0.0 & 0.0 & 1.0 & 4.4 & 7.25 & 6.7 \\
\hline Total & 162.0 & & 147.0 & & 23.0 & & 108.0 & \\
\hline
\end{tabular}

Owing to the relatively few lead analyses carried out it is not possible to present a similar analysis for this metal. The average lead concentrations recorded for each tissue, however, varied little, from $1.07 \pm 0.75 \mu \mathrm{g} / \mathrm{g}$ in brain to $1.37 \pm 0.79 \mu \mathrm{g} / \mathrm{g}$ in liver, $2.05 \pm 3.10$ in kidney and $2.42 \pm 3.56 \mu \mathrm{g} / \mathrm{g}$ in muscle.

\section{Relationship between metal concentration and maturity status}

There were only six species (all odontocetes) for which a sufficient number of samples had been analysed to investigate possible changes in metal concentration with the age of the individual. These were the pygmy sperm whale and the Risso's, bottlenose, dusky, Heaviside's and common dolphins. Even in these cases, the number of individuals sampled (11-40) was only sufficient for an examination on a gross scale, i.e. between immature (calves plus juveniles) and mature (sub-adults plus adults) animals of both sexes combined, and only for four metals (zinc, copper, cadmium and mercury). Comparisons were confined to those tissues in which the highest concentrations of each metal were usually found, i.e. the liver for zinc, copper and mercury and the kidney for cadmium (Table 4).

Mean values were compared using a two-tailed Mann-Whitney $U$ test. Significantly higher hepatic values of mercury in mature individuals were found for the pygmy sperm whale and the Risso's, dusky and common dolphins. Significantly higher renal values of

Table 4

Comparison of concentrations of hepatic zinc, copper, mercury and renal cadmium in immature and mature individuals of six cetaceans in southern African waters. All concentrations are expressed in $\mu \mathrm{g} / \mathrm{g}$ wet weight.

\begin{tabular}{|c|c|c|c|c|c|c|c|c|c|}
\hline \multirow[b]{2}{*}{ Species } & \multirow[b]{2}{*}{ Maturity } & \multicolumn{2}{|c|}{ Hepatic zinc } & \multicolumn{2}{|c|}{ Hepatic copper } & \multicolumn{2}{|c|}{ Renal cadmium } & \multicolumn{2}{|c|}{ Hepatic mercury } \\
\hline & & No. & Mean \pm SD & No. & Mean $\pm S D$ & No. & Mean \pm SD & No. & Mean $\pm \mathrm{SD}$ \\
\hline \multirow[t]{2}{*}{ Pygmy sperm whale } & Immature & 4 & $28.5 \pm 13.7$ & 4 & $18.3 \pm 21.9$ & 3 & $2.4 \pm 1.2$ & 3 & $0.9 \pm 0.8$ \\
\hline & Mature & 7 & $21.9 \pm 4.7$ & 7 & $3.0 \pm 1.2$ & 7 & $15.1 \pm 10.7$ & 6 & $6.1 \pm 5.6^{1}$ \\
\hline \multirow[t]{2}{*}{ Risso's dolphin } & Immature & 9 & $34.6 \pm 40.9$ & 9 & $4.2 \pm 1.7$ & 6 & $9.2 \pm 1.9$ & 8 & $2.3 \pm 4.6$ \\
\hline & Mature & 20 & $28.1 \pm 13.0$ & 20 & $5.7 \pm 2.7$ & 20 & $24.1 \pm 16.1^{2}$ & 20 & $45.6 \pm 32.2^{3}$ \\
\hline \multirow[t]{2}{*}{ Bottlenose dolphin } & Immature & 7 & $49.7 \pm 23.2$ & 7 & $19.4 \pm 16.2$ & 4 & $7.8 \pm 7.0$ & 7 & $2.5 \pm 3.4$ \\
\hline & Mature & 5 & $39.9 \pm 21.1$ & 5 & $5.4 \pm 1.4$ & 5 & $9.1 \pm 4.8$ & 4 & $71.0 \pm 104.3$ \\
\hline \multirow[t]{2}{*}{ Dusky dolphin } & Immature & 12 & $18.1 \pm 8.1$ & 12 & $5.1 \pm 3.5$ & 10 & $3.5 \pm 1.8$ & 12 & $1.3 \pm 1.1$ \\
\hline & Mature & 8 & $34.4 \pm 23.0$ & 8 & $6.5 \pm 4.1$ & 8 & $8.3 \pm 5.0^{2}$ & 8 & $7.7 \pm 9.2$ \\
\hline \multirow[t]{2}{*}{ Heaviside's dolphin } & Immature & 5 & $43.0 \pm 23.3$ & 5 & $9.7 \pm 2.4$ & 4 & $8.4 \pm 8.3$ & 4 & $0.6 \pm 0.4$ \\
\hline & Mature & 7 & $45.9 \pm 18.1$ & 7 & $11.4 \pm 4.2$ & 7 & $11.0 \pm 7.3$ & 6 & $6.2 \pm 9.7$ \\
\hline \multirow[t]{2}{*}{ Common dolphin } & Immature & 26 & $40.2 \pm 19.7$ & 26 & $7.5 \pm 3.8$ & 23 & $4.0 \pm 3.3$ & 25 & $5.3 \pm 5.5$ \\
\hline & Mature & 14 & $26.8 \pm 10.1^{\prime}$ & 14 & $6.0 \pm 2.4$ & 13 & $8.6 \pm 5.3^{3}$ & 13 & $22.0 \pm 16.2^{3}$ \\
\hline
\end{tabular}

Significant at $5 \%$ level. ${ }^{2}$ Significant at $2 \%$ lcvel. ${ }^{3}$ Significant at $1 \%$ level (or less). 
cadmium were found in mature Risso's, dusky and common dolphin individuals. The only significant reduction in the concentration of a metal with age occurred in the common dolphin where hepatic zinc levels were lower in mature animals.

\section{Inter-specific variation in metal concentrations}

Appendix Figs 1 - 5 (hereafter simply referred to as 'Figs 1 - 5') show the mean concentrations recorded for each metal for each tissue for each age category of each species. Comparisons between species are complicated by the small sample sizes, high individual variability and correlation with age (at least in some species and metals).

For the five species where three or more adults were examined, hepatic zinc levels averaged between about 20 and $50 \mu \mathrm{g} / \mathrm{g}$ (Table 5), with renal levels equivalent or only slightly less. Inspection of Fig. 1 fails to suggest any consistent trend in concentration with age between species. Although there are indications of a trend for some species (minke whale, dwarf sperm whale, striped dolphin and dusky dolphin) sample sizes precluded statistical analysis apart from the significant link reported for the common dolphin in Table 4. Few adult baleen whales were examined. High zinc concentrations were recorded in the liver of right $(88.1 \pm 47.7 \mu \mathrm{g} / \mathrm{g})$ and Bryde's $(87.0 \mu \mathrm{g} / \mathrm{g})$ whale calves and in an adult pygmy right whale $(191 \mu \mathrm{g} / \mathrm{g})$.

Table 5

Concentrations of four metals for cases where samples for three or more physically mature specimens were analysed. Concentrations are expressed in $\mu \mathrm{g} / \mathrm{g}$ wet mass. Figures following \pm refer to one standard deviation of the mean.

\begin{tabular}{lllcc}
\hline Species & Hepatic $\mathrm{Zn}$ & Hepatic $\mathrm{Cu}$ & Hepatic $\mathrm{Hg}$ & Renal Cd \\
\hline Dwarf sperm whale & $22.6 \pm 5.4$ & $2.8 \pm 1.3$ & $7.2 \pm 5.6$ & $20.82 \pm 8.4$ \\
Blainville's beaked whale & $22.7 \pm 7.5$ & $5.0 \pm 2.0$ & $46.9 \pm 26.2$ & $32.3 \pm 17.8$ \\
Strap-toothed whale & $49.7 \pm 20.2$ & $8.7 \pm 1.7$ & $93.8 \pm 57.1$ & $76.9 \pm 39.1$ \\
Bottlenose dolphin & $39.0 \pm 20.5$ & $4.6 \pm 0.4$ & & $11.0 \pm 5.2$ \\
Common dolphin & $19.3 \pm 5.1$ & $3.9 \pm 0.9$ & $34.4 \pm 15.0$ & $7.6 \pm 2.3$ \\
\hline
\end{tabular}

Concentrations of copper in the liver of adults of the same five odontocetes averaged between about 3 and $9 \mu \mathrm{g} / \mathrm{g}$ (Table 5). Inspection of Fig. 2 also fails to suggest any consistent age related change in concentration levels between species. As for zinc, high hepatic copper concentrations were recorded in right (169.5 \pm 104.3$)$ and Bryde $s$ (118.0) whale calves and in an adult pygmy right whale $(100 \mu \mathrm{g} / \mathrm{g})$.

Concentrations of cadmium in the kidneys of adults of the same species were highly variable (from around 7 to $77 \mu \mathrm{g} / \mathrm{g}$ ) as shown in Table 5. A general tendency for concentrations to increase with age is apparent from Fig. 3 (and was demonstrated statistically for three species as shown in Table 4). Renal cadmium values for baleen whale calves and juveniles were low $(0.15-0.5 \mu \mathrm{g} / \mathrm{g})$. The value for the adult pygmy right whale however was $46.8 \mu \mathrm{g} / \mathrm{g}$, similar to some of the odontocetes.

Inspection of Fig. 4 shows a clear indication lor mercury concentrations in the liver to increase with age in several species, and such an increase has been statistically demonstrated in Table 4 for four species. In the four species for which there were analyses from three or more adults, average mercury concentrations were highly variable (from around 7 to $94 \mu \mathrm{g} / \mathrm{g}$ ) as shown in Table 5. All the baleen whales examined had very low hepatic mercury levels $(<1 \mu \mathrm{g} / \mathrm{g}$ ), although only one adult (a pygmy right whale) was examined. 
The data for lead concentrations are so few and so dispersed among species and ages (Fig. 5 ) that it is difficult to draw any meaningful conclusions. Values are generally low, less than $5 \mu \mathrm{g} / \mathrm{g}$ across all species and tissues, with the highest concentration being $17.6 \mu \mathrm{g} / \mathrm{g}$ in the kidney of a sub-adult pygmy sperm whale.

\section{DISCUSSION}

For the metals examined here, the site specificity recorded agrees largely with previous findings for cetaceans. In a review of the literature, Bowles (1999) lists the liver as the tissue most commonly containing the highest concentrations of mercury (12/12 species) and the liver (or kidney) as containing the highest concentrations of copper (10/10 species). The kidney (or kidney and liver) was the tissue most commonly containing the highest concentration of cadmium (12/12 species). Excluding skin and bone (which were not sampled in this study), highest concentrations of zinc were found in the liver $(6 / 10$ species) or kidney ( $2 / 10$ species) or both ( $1 / 10$ species); the tenth species had its highest concentration in the muscle. Site specificity for lead was not often determined (in general, lead concentrations are highest in bone which was not examined in this study). The present results extend Bowles' listing by several species, including the dwarf sperm whale, Blainville's beaked whale, strap-toothed whale, Risso's dolphin, dusky dolphin, Heaviside's dolphin and common dolphin.

Relationships between maturity status and the concentrations of zinc, copper, cadmium and mercury in the liver/kidney recorded in this paper for pygmy sperm whales, Risso's dolphins, bottlenose dolphins, dusky dolphins, Heaviside's dolphins and common dolphins generally agreed with trends found with age in other or the same species. For most essential metals there is no clear age relationship (Bowles, 1999), and the only trend found here was for hepatic zinc concentrations to decline after maturity in common dolphins. High concentrations of zinc relative to those in adults have been found in the livers of neonatal harbour porpoises (Law et al., 1992; Paludan-Muller et al., 1993), and in striped dolphins hepatic zinc concentrations increased during gestation and lactation but declined after weaning (Honda and Tatsukawa, 1983). These trends are not inconsistent with the pre-/post-maturity contrast seen here in common dolphins. Elevated hepatic copper levels in neonates, as evident here for right whales and Bryde's whales, have been previously recorded in several cetacean species (Bowles, 1999). Of the non-essential metals, a strong correlation with age has been demonstrated for mercury in at least eight different cetacean species; harbour porpoises, Globicephala spp., striped dolphins, white-beaked dolphins, narwhals, white whales, fin whales and minke whales (Bowles, 1999). To these can now be added pygmy sperm whales, Risso's dolphins, dusky dolphins and Heaviside's dolphins. Hepatic levels of cadmium showed increases with age in at least some post-natal stages of striped dolphins, Globicephala spp., narwhals, white whales and harbour porpoises (Bowles, 1999). The significant increases in renal cadmium levels with maturity in Risso's dolphins, dusky dolphins and Common dolphins demonstrated here are consistent with this trend.

Comparisons of the levels of metals found in cetaceans off southern Africa with those elsewhere is complicated by possible inter-specific differences in bioaccumulation rates, differing ages (and sexes) of animals in the samples, and inconsistent analytical techniques (Aguilar et al., 1999). Furthermore, the high individual variability in concentration levels of non-essential metals means that adequate sample sizes must be available for a valid statistical comparison. Bowles (1999) considers that mercury is the only metal which can be readily compared between regions as it accumulates throughout life and has been widely researched. Of the seven species for which he tables values for hepatic mercury from a number of geographical regions (striped dolphins, spotted dolphins, Globicephala spp., narwhals, white 
whales, harbour porpoises, bottlenose dolphins and white-beaked dolphins), only the bottlenose dolphin is common to the list of species for which an adequate number of adult specimens was analysed in this paper (Table 4). Unfortunately the data for this species tabled by Bowles come from a single specimen, so that a comparison is hardly meaningful. Kemper et al. (1994) give a range of values of $0.14-10.18 \mu \mathrm{g} / \mathrm{g}$ for hepatic mercury in nine bottlenose dolphins from Australian waters; four out of twelve values for hepatic mercury from southern African bottlenose dolphins exceeded this range. However, no associated ages are available for the Australian animals, so the significance of this apparent difference cannot be determined.

Although the physiological effects of the metal concentrations found were not part of the investigation, it is interesting to compare the levels recorded with proposed tolerance limits for the metals. Before doing so however, it should be noted that tolerance limits are usually based on information from a range of species and extrapolation from one species to another requires considerable caution. Wagemann and Muir (1984) suggested a range of $100-400 \mu \mathrm{g} / \mathrm{g}$ for hepatic mercury ${ }^{1}$, whilst Law (in Bowles, 1999), in the context of humans, proposed a range of $200-400 \mu \mathrm{g} / \mathrm{g}$ for renal cadmium and $40-200 \mu \mathrm{g} / \mathrm{g}$ for hepatic cadmium, as tolerance limits above which toxic effects could occur. Levels of hepatic mercury within (but not exceeding) Wagemann and Muir's tolerance limits only occurred in two out of 151 individuals analysed here, a sub-adult bottlenose dolphins $(251.2 \mu \mathrm{g} / \mathrm{g})$ and an adult strap-toothed whales $(171.0 \mu \mathrm{g} / \mathrm{g}$ ). There were no individuals (amongst 142 analysed) with renal cadmium levels that equalled or exceeded Law's proposed tolerance limits. There were six out of 134 cetaceans analysed, however, with hepatic cadmium levels that fell within (but did not exceed) Law's tolerance limits: two adults strap-toothed whales (49.5 and $78.4 \mu \mathrm{g} / \mathrm{g}$ ), a juvenile hourglass dolphin $(41.2 \mu \mathrm{g} / \mathrm{g})$ and three sub-adult Risso's dolphins $(46.7,59.9$ and $72.3 \mu \mathrm{g} / \mathrm{g}$ ). Considering the nature of the sample (dominated by stranded individuals, in which debilitated animals might be expected to feature strongly), the absence of individuals with mercury or cadmium levels exceeding the proposed tolerance ranges suggests that contamination of cetaceans with these metals is not as yet a serious problem in the region noting however, the problems associated from extrapolating from one species to another.

\section{ACKNOWLEDGEMENTS}

Numerous people assisted with the collection of material at strandings and elsewhere: these included Michael Meyer, Keiko Sekiguchi, Ken Findlay, Derek Ohland. Martin Haupt, Gus van Dyk, Peter Sims, Mike Combrinck, Kevin Smith, Peter Heather-Noon, Deon Kotze, Herman Oosthuizen and Colin Potts. Their help under sometimes unpleasant circumstances is much appreciated. PBB was supported by the Foundation for Research Development, and the South African Marine Corporation through WWF-South Africa.

\section{RFFERENCES}

Aguilar, A., Borrell, A. and Pastor, T. 1999. Biological factors affecting variability of persistent pollutant levels in cetaceans. J. Cetacean Res. Manage. (special issue) 1:00-.

Bowles, D. 1999. An overview of the concentrations and effects of heavy metals in cetacean species. $J$. Cetacean Res. Manage. (special issue) 1:125-48.

Evans, S.J.. Johnson, M.S. and Leah, R.T. 1986. Determination of mercury in fish tissue. a rapid automated technique for routine analysis. Varian Instruments at Work. Atomic Absorbtion AA-60 (May). 6pp.

Honda, K. and Tatsukawa, R. 1983. Distribution of cadmium and zinc in tissues and organs, and their age related changes in striped dolphins, Stenella coeruleoalba. Arch. Environ. Contam. Toxicol. 15:543-50.

1 The toxic form of mercury is methylmercury. This was not analysed in this study and this should be borne in mind in any consideration of tolerance limits. 
Kemper, C., Gibbs, P.. Obendorf, D., Marvanek, S. and Lenghaus, C. 1994. A review of heavy metal and organochlorine levels in marine mammals in Australia. Sci. Total Environ. 154(2-3):129-39.

Law, R.J., Jones, B.R., Baker, J.R., Kennedy, S., Milne, R. and Morris, R.J. 1992. Trace metais in the livers of marine mammals from the Welsh Coast and the Irish Sea. Mar. Poll. Bull. 24(6):296-304.

Paludan-Muller, P., Agger, C.T., Diet\%, R. and Kinze, C.C. 1993. Mercury, cadmium, zinc, copper and selenium in harbour porpoise (Phocesena phocoena) from West Greenland. Polar Biol. 13(5):311-20.

Wagemann. R. and Muir, D.G.C. 1984. Concentrations of heavy metals and organochlorines in marine mammals of northern waters: overview and evaluation. Can. Tech. Rep. Fish. Aquat. Sci. 1279:1-97.

Zak, J., Porter, M.D. and Kuwana, P. 1983. Thin-layer electrochemical cell for long optical path length observation of solution species. Anal. Chem. 55:2219-22.

[Appendix Table I and Figs 1 - 5 begin overleaf] 


\section{Appendix}

\section{Appendix Table 1}

Details of cetaceans from southern Africa sampled for heavy metal analysis. Key: $C=$ calf, $J=$ juvenile, $\mathrm{SA}=$ subadult, $\mathrm{A}=$ adult $\mathrm{S}=$ stranding, $\mathrm{I}=$ incidental catch, $\mathrm{P}=$ special permit catch.

\begin{tabular}{|c|c|c|c|c|c|c|c|c|}
\hline Field no. & Length $(\mathrm{cm})$ & Sex & Weight(kg) & Age & Origin & Date & \multicolumn{2}{|c|}{ Location } \\
\hline \multicolumn{9}{|c|}{ Southern right whale } \\
\hline $86 / 29$ & 460 & F & - & $\mathrm{C}$ & $\mathrm{s}$ & 20 Aug. 1986 & $34^{\circ} 33^{\prime} \mathrm{S}$ & $19^{\circ} 21^{\prime} \mathrm{E}$ \\
\hline $86 / 32$ & 485 & $M$ & - & $\mathrm{C}$ & $\mathrm{s}$ & 2 Sep. 1986 & $34^{\circ} 33^{\prime} \mathrm{S}$ & $20^{\circ} 25^{\prime} \mathrm{E}$ \\
\hline $89 / 23$ & 463 & $M$ & - & $\mathrm{C}$ & $\mathrm{s}$ & 31 Jul. 1989 & $33^{\circ} 38^{\prime} \mathrm{S}$ & $18^{\circ} 23^{\prime} \mathrm{E}$ \\
\hline $90 / 29$ & 480 & $\mathbf{F}$ & 1,146 & $\mathrm{C}$ & $\mathrm{s}$ & 14 Aug. 1990 & $34^{\circ} 24^{\prime} \mathrm{S}$ & $19^{\circ} 16^{\prime} \mathrm{E}$ \\
\hline \multicolumn{9}{|c|}{ Pygmy right whale } \\
\hline $82 / 11$ & 596 & $\mathrm{M}$ & 2,716 & A & $\mathrm{S}$ & 25 May 1982 & $34^{\circ} 19^{\prime} \mathrm{S}$ & $18^{\circ} 28^{\prime} \mathrm{E}$ \\
\hline $89 / 03$ & 332 & $\mathrm{~F}$ & 408 & $\mathrm{~J}$ & s & 17 Feb. 1989 & $22^{\circ} 50^{\prime} \mathrm{S}$ & $14^{\circ} 31^{\prime} \mathrm{E}$ \\
\hline \multicolumn{9}{|c|}{ Minke whale } \\
\hline $83 / 17$ & 666 & $M$ & 4,310 & $\mathrm{SA}$ & $\mathrm{s}$ & 30 Mar. 1983 & $32^{\circ} 43^{\prime} \mathrm{S}$ & $17^{\circ} 59^{\prime} \mathrm{E}$ \\
\hline $84 / 34$ & 333 & $\mathrm{~F}$ & - & $\mathrm{C}$ & $\mathrm{s}$ & 20 Nov. 1984 & $33^{\circ} 54^{\prime} \mathrm{S}$ & $18^{\circ} 26^{\prime} \mathrm{E}$ \\
\hline $89 / 01$ & 429 & $\mathrm{~F}$ & - & $\mathbf{J}$ & $\mathrm{s}$ & 3 Jan. 1989 & $33^{\circ} 58^{\prime} \mathrm{S}$ & $18^{\circ} 22^{\prime} \mathrm{L}$ \\
\hline \multicolumn{9}{|c|}{ Bryde's whale } \\
\hline $84 / 20$ & 409 & $\mathrm{~F}$ & 514 & $\mathrm{C}$ & $\mathrm{S}$ & 10 Jul. 1984 & $34 " 46 \mathrm{~S}$ & $19^{\circ} 52^{\prime} \mathrm{E}$ \\
\hline $84 / 28$ & 616 & $\mathrm{M}$ & - & $\mathrm{J}$ & $\mathrm{s}$ & 9 Nov. 1984 & $32 " 44 \mathrm{~S}$ & $18^{\circ} 01^{\prime} \mathrm{E}$ \\
\hline $88 / 04$ & 804 & $\mathrm{M}$ & - & $\mathrm{J}$ & $\mathrm{S}$ & 15 Feb. 1988 & $34^{\circ} 46^{\prime} \mathrm{S}$ & $19^{\circ} 42^{\prime} \mathrm{E}$ \\
\hline \multicolumn{9}{|c|}{ Humpback whale } \\
\hline $90 / 40$ & 615 & $\mathrm{~F}$ & - & $\mathrm{C}$ & $\mathrm{s}$ & 14 Dec. 1990 & $33^{\circ} 09^{\prime} \mathrm{S}$ & $17^{\circ} 59^{\prime} \mathrm{E}$ \\
\hline \multicolumn{9}{|c|}{ Sperm whale } \\
\hline $86 / 19$ & 1605 & $\mathrm{M}$ & - & A & $\mathrm{s}$ & 13 May 1986 & $34^{\circ} 08^{\prime} \mathrm{S}$ & $18^{\circ} 20^{\prime} \mathrm{E}$ \\
\hline \multicolumn{9}{|c|}{ Pygmy sperm whale } \\
\hline $82 / 04$ & 288 & $\mathrm{~F}$ & 344 & A & $\mathrm{s}$ & 6 Feb. 1982 & $32 ' 52 ' \mathrm{~S}$ & $17^{\circ} 53^{\prime} \mathrm{E}$ \\
\hline $82 / 20$ & 299 & $\mathrm{~F}$ & 329 & A & $\mathrm{S}$ & 26 Sep. 1982 & $34^{\prime} 23{ }^{\prime} \mathrm{S}$ & $20^{\circ} 5 l^{\prime} \mathrm{E}$ \\
\hline $82 / 21$ & 215 & $\mathrm{M}$ & 161 & $\mathrm{~J}$ & $\mathrm{~S}$ & 26 Sep. 1982 & $34^{\prime \prime} 23$ 'S & $20^{\circ} 5 l^{\prime} \mathrm{E}$ \\
\hline $83 / 20$ & 301 & $\mathrm{~F}$ & 350 & A & $\mathrm{S}$ & 6 May 1983 & $34^{\prime \prime} 23^{\prime} \mathrm{S}$ & $20^{\circ} 5 l^{\prime} \mathrm{E}$ \\
\hline $83 / 21$ & 191 & $\mathrm{M}$ & 127 & $\mathrm{C}$ & $\mathrm{S}$ & 6 May 1983 & $34^{\prime \prime} 23^{\prime} \mathrm{S}$ & $20^{\circ} 5 l^{\prime} \mathrm{E}$ \\
\hline $83 / 27$ & 147 & $\mathrm{M}$ & 68 & $\mathrm{C}$ & $\mathrm{S}$ & I1 Jun. 1983 & $34^{\prime \prime} 22 \mathrm{~S}$ & $18^{\circ} 52^{\prime} \mathrm{E}$ \\
\hline $83 / 33$ & 256 & $\mathrm{~F}$ & 272 & $\mathrm{~J}$ & $\mathrm{~S}$ & 23 Sep. 1983 & $34^{\prime \prime} 25 ' \mathrm{~S}$ & $19^{\circ} 15^{\prime} \mathrm{E}$ \\
\hline $84 / 24$ & 301 & $\mathrm{~F}$ & - & A & $\mathrm{S}$ & 10 Aug. 1984 & $34^{\prime} 211^{\prime} \mathrm{S}$ & $19^{\circ} 03^{\prime} \mathrm{E}$ \\
\hline $84 / 26$ & 238 & $\mathrm{~F}$ & - & SA & $\mathrm{s}$ & 4 Sep. 1984 & $22 " 50 \mathrm{~S}$ & $14^{\circ} 31 \mathrm{E}$ \\
\hline $86 / 17$ & 321 & $\mathrm{~F}$ & 480 & $\mathrm{~A}$ & $\mathrm{~S}$ & 11 Apr. 1986 & $34^{\prime \prime} 30^{\prime} \mathrm{S}$ & $20^{\circ} 28^{\prime} \mathrm{E}$ \\
\hline $86 / 22$ & 218 & $\mathbf{M}$ & 186 & SA & $\mathrm{S}$ & 23 May 1986 & $33^{\prime \prime} 27 ' \mathrm{~S}$ & $18^{\circ} 16^{\prime} \mathrm{E}$ \\
\hline \multicolumn{9}{|c|}{ Dwarf sperm whale } \\
\hline $84 / 36$ & 178 & $\mathbf{M}$ & 110 & $\mathrm{~J}$ & $S$ & 26 Nov. 1984 & $34^{\prime \prime} 06^{\prime} \mathrm{S}$ & $18^{\circ} 28^{\prime} \mathrm{F}$ \\
\hline $84 / 35$ & 230 & M & 200 & $\mathrm{SA}$ & $\mathrm{S}$ & 26 Nov. 1984 & $34^{\circ} 06^{\prime} \mathrm{S}$ & $18^{\circ} 28^{\prime} \mathrm{S}$ \\
\hline $85 / 02$ & 251 & $\mathrm{~F}$ & & A & $\mathrm{S}$ & 8 Mar. 1985 & $34^{\prime \prime} 30^{\prime} \mathrm{S}$ & $20^{\prime} 28^{\prime} \mathrm{E}$ \\
\hline $88 / 02$ & 226 & $\mathrm{~F}$ & 178 & SA & $\mathrm{S}$ & 27 Jan. 1988 & $34^{\prime \prime} 31$ 'S & $20^{\prime} 27^{\prime} \mathrm{E}$ \\
\hline $88 / 20$ & 231 & $\mathrm{~F}$ & 173 & $\mathrm{~J}$ & $\mathrm{~S}$ & 14 Jul. 1988 & $34^{\circ} 37^{\prime} \mathrm{S}$ & $19^{\prime \prime} 24^{\prime} \mathrm{E}$ \\
\hline $90 / 34$ & 238 & $\mathbf{M}$ & 191 & SA & $\mathrm{S}$ & 16 Oct. 1990 & $32 " 47 ' S$ & $18^{\circ} 04^{\prime} \mathrm{E}$ \\
\hline \multicolumn{9}{|c|}{ Southern bottlenose whale } \\
\hline $90 / 02$ & 655 & $\mathrm{~F}$ & - & SA & $\mathrm{S}$ & 10 Jan. 1990 & $32+66 \mathrm{~S}$ & $18^{\circ} 08^{\prime} \mathrm{E}$ \\
\hline \multicolumn{9}{|c|}{ Cuvier's beaked whale } \\
\hline $89 / 21$ & 557 & $\mathrm{~F}$ & - & $\mathrm{J}$ & $\mathrm{S}$ & 17 Jul. 1989 & $33^{\circ} 38^{\prime} \mathrm{S}$ & $18^{\circ} 23^{\prime} \mathrm{E}$ \\
\hline
\end{tabular}




\begin{tabular}{|c|c|c|c|c|c|c|c|c|}
\hline Field no. & Length(cm) & Sex & Weight(kg) & Age & Origin & Date & \multicolumn{2}{|c|}{ Location } \\
\hline \multicolumn{9}{|c|}{ Blainville's beaked whale } \\
\hline $84 / 11$ & 346 & $\mathrm{~F}$ & 460 & $\mathrm{~J}$ & $\mathrm{~S}$ & 12 Mar. 1984 & $34^{\circ} 06 \mathrm{~S}$ & $18^{\circ} 28^{\prime} \mathrm{E}$ \\
\hline $84 / 12$ & 454 & F & 986 & A & $\mathrm{S}$ & 15 Mar. 1984 & $34^{\circ} 50^{\prime} \mathrm{S}$ & $20^{\circ} 00^{\prime} \mathrm{E}$ \\
\hline $84 / 15$ & 225 & $\mathrm{M}$ & 159 & $\mathrm{C}$ & $\mathbf{S}$ & 30 Apr. 1984 & $34^{\circ} 49^{\prime} \mathrm{S}$ & $19^{\circ} 57^{\prime} \mathrm{E}$ \\
\hline $84 / 16$ & 454 & $\mathrm{~F}$ & - & A & S & 30 Apr. 1984 & $34^{\circ} 49^{\prime} \mathrm{S}$ & $19^{\circ} 57^{\prime} \mathrm{E}$ \\
\hline $84 / 23$ & 425 & $\mathrm{~F}$ & - & A & $S$ & 31 Jul. 1984 & $34^{\circ} 28^{\prime} \mathrm{S}$ & $20^{\circ} 32^{\prime} \mathrm{E}$ \\
\hline $86 / 23$ & 376 & M & 624 & A & S & 7 Jun. 1986 & $34^{\circ} 46^{\prime} \mathrm{S}$ & $19^{\circ} 52^{\prime} \mathrm{E}$ \\
\hline $88 / 09$ & 436 & $\mathrm{M}$ & - & A & $S$ & 5 Apr. 1988 & $34^{\circ} 46^{\prime} \mathrm{S}$ & $19^{\circ} 42^{\prime} \mathrm{E}$ \\
\hline $88 / 25$ & 413 & M & - & A & $\mathrm{S}$ & 18 Oct. 1988 & $34^{\circ} 46^{\prime} \mathrm{S}$ & $18^{\circ} 03^{\prime} \mathrm{E}$ \\
\hline $88 / 27$ & 401 & $\mathrm{~F}$ & - & A & $\mathrm{S}$ & 25 Nov. 1988 & $34^{\circ} 46^{\prime} \mathrm{S}$ & $18^{\circ} 03^{\prime} \mathrm{E}$ \\
\hline \multicolumn{9}{|c|}{ Strap-toothed whale } \\
\hline $82 / 09$ & 562 & $\mathrm{~F}$ & 690 & A & $\mathrm{S}$ & $6 \mathrm{Apr}, 1982$ & $32^{\circ} 43^{\prime} \mathrm{S}$ & $17^{\circ} 59^{\prime} \mathrm{E}$ \\
\hline $82 / 10$ & 318 & $\mathrm{~F}$ & 415 & $\mathrm{C}$ & S & 6 Apr. 1982 & $32^{\circ} 43^{\prime} \mathrm{S}$ & $17^{\circ} 59^{\prime} \mathrm{E}$ \\
\hline $83 / 14$ & 553 & $\mathrm{~F}$ & 1,568 & A & $\mathrm{S}$ & 20 Mar. 1983 & $32^{\circ} 42^{\prime} \mathrm{S}$ & $18^{\circ} 14^{\prime} \mathrm{E}$ \\
\hline $83 / 16$ & 526 & $\mathrm{~F}$ & 1,618 & A & S & 30 Mar. 1983 & $32^{\circ} 45^{\prime} \mathrm{S}$ & $18^{\circ} 01^{\prime} \mathrm{E}$ \\
\hline $85 / 10$ & 500 & M & - & A & $S$ & 15 Apr. 1985 & $32^{\circ} 43^{\prime} \mathrm{S}$ & $17^{\circ} 58^{\prime} \mathrm{E}$ \\
\hline \multicolumn{9}{|c|}{ True's beaked whale } \\
\hline $86 / 30$ & 318 & F & 351 & $\mathrm{~J}$ & $\mathrm{~S}$ & 22 Aug. 1986 & $32^{\circ} 33^{\prime} \mathrm{S}$ & $18^{\circ} 19^{\prime} \mathrm{E}$ \\
\hline $86 / 38$ & 417 & - & - & $\mathbf{J}$ & s & 2 Nov. 1986 & $33^{\circ} 47^{\prime} \mathrm{S}$ & $18^{\circ} 22^{\prime} \mathrm{E}$ \\
\hline \multicolumn{9}{|c|}{ Long-finned pilot whale } \\
\hline $83 / 44$ & 381 & $\mathbf{M}$ & 520 & $\mathrm{~J}$ & $\mathrm{~s}$ & 19 Dec. 1983 & $33^{\circ} 24 ' S$ & $20^{\circ} 52^{\prime} \mathrm{E}$ \\
\hline $90 / 25$ & 371 & $\mathrm{~F}$ & - & SA & S & 2 Jun. 1990 & $33^{\circ} 21^{\prime} \mathrm{S}$ & $18^{\circ} 09^{\prime} \mathrm{E}$ \\
\hline $90 / 26$ & 410 & $\mathrm{~F}$ & - & A & $\mathrm{S}$ & 6 Jun. 1990 & $34^{\circ} 28^{\prime} \mathrm{S}$ & $19^{\circ} 2 l^{\prime} E$ \\
\hline \multicolumn{9}{|c|}{ Risso's dolphin } \\
\hline $82 / 18$ & 302 & $\mathrm{~F}$ & 325 & A & $\mathbf{S}$ & 24 Aug. 1982 & $32^{\circ} 43^{\prime} \mathrm{S}$ & $17^{\circ} 56^{\prime} \mathrm{E}$ \\
\hline $83 / 15$ & 303 & $\mathrm{~F}$ & 350 & SA & $\mathrm{S}$ & 23 Mar. 1983 & $33^{\circ} 48^{\prime} \mathrm{S}$ & $18^{\circ} 28^{\prime} \mathrm{E}$ \\
\hline $83 / 18$ & 152 & $\mathrm{~F}$ & 32 & $\mathrm{C}$ & $\mathrm{S}$ & 30 Mar. 1983 & $34^{\circ} 07^{\prime} \mathrm{S}$ & $22^{\circ} 08^{\prime} \mathrm{E}$ \\
\hline $83 / 25 / 1$ & 297 & $\mathrm{~F}$ & 327 & $\mathrm{SA}$ & $\mathrm{s}$ & 27 May 1983 & $34^{\circ} 19^{\prime} \mathrm{S}$ & $18^{\circ} 28^{\prime} \mathrm{E}$ \\
\hline $83 / 25 / 2$ & 341 & $\mathbf{M}$ & 486 & SA & $\mathrm{S}$ & 27 May 1983 & $34^{\circ} 19^{\prime} \mathrm{S}$ & $18^{\circ} 28^{\prime} \mathrm{E}$ \\
\hline $83 / 25 / 3$ & 315 & $\mathbf{M}$ & 404 & SA & $\mathrm{s}$ & 27 May 1983 & $34^{\circ} 19^{\prime} \mathrm{S}$ & $18^{\circ} 28^{\prime} \mathrm{E}$ \\
\hline $83 / 25 / 4$ & 331 & M & 450 & SA & $\mathbf{S}$ & 27 May 1983 & $34^{\circ} 19^{\prime} \mathrm{S}$ & $18^{\circ} 28^{\prime} \mathrm{E}$ \\
\hline $83 / 25 / 5$ & 327 & M & 468 & SA & $\mathrm{s}$ & 27 May 1983 & $34^{\circ} 19^{\prime} \mathrm{S}$ & $18^{\circ} 28^{\prime} \mathrm{E}$ \\
\hline $83 / 25 / 6$ & 292 & $\mathrm{~F}$ & 292 & SA & $\mathrm{S}$ & 27 May 1983 & $34^{\circ} 19^{\prime} \mathrm{S}$ & $18^{\circ} 28^{\prime} \mathrm{E}$ \\
\hline $83 / 25 / 7$ & 301 & F & 345 & $\mathrm{SA}$ & $s$ & 27 May 1983 & $34^{\circ} 19^{\prime} \mathrm{S}$ & $18^{\circ} 28^{\prime} \mathrm{E}$ \\
\hline $83 / 25 / 8$ & 284 & $\mathrm{~F}$ & 304 & $\mathrm{SA}$ & $\mathrm{s}$ & 27 May 1983 & $34^{\circ} 19^{\prime} \mathrm{S}$ & $18^{\circ} 28^{\prime} \mathrm{E}$ \\
\hline $83 / 30$ & 188 & $\mathbf{M}$ & 67 & $\mathrm{C}$ & $\mathrm{S}$ & 18 Jun. 1983 & $34^{\circ} 01^{\prime} \mathrm{S}$ & $18^{\circ} 20^{\prime} \mathrm{E}$ \\
\hline $83 / 34$ & 225 & M & 125 & $\mathrm{~J}$ & $\mathrm{~S}$ & 4 Oct. 1983 & $34^{\prime \prime} 12^{\prime} \mathrm{S}$ & $18^{\circ} 27^{\prime} \mathrm{E}$ \\
\hline $84 / 25$ & 314 & M & 350 & SA & $\mathrm{S}$ & 31 Aug. 1984 & $34^{\circ} 12^{\prime} \mathrm{S}$ & $18^{\circ} 27^{\prime} \mathrm{E}$ \\
\hline $88 / 11$ & 317 & M & 375 & SA & $S$ & 17 Jun. 1988 & $34^{\circ} 22^{\prime} \mathrm{S}$ & $19^{\circ} 51^{\prime} \mathrm{E}$ \\
\hline $88 / 12$ & 290 & $F$ & 313 & SA & $\mathrm{S}$ & 17 Jun. 1988 & $34^{\circ} 22^{\prime} \mathrm{S}$ & $19^{\circ} 51^{\prime} \mathrm{E}$ \\
\hline $88 / 13$ & 315 & M & 422 & SA & $S$ & 17 Jun. 1988 & $34^{\circ} 22^{\prime} \mathrm{S}$ & $19^{\circ} 51^{\prime} \mathrm{E}$ \\
\hline $89 / 05$ & 165 & $\mathbf{F}$ & 46 & $\mathrm{C}$ & S & 21 Feb. 1989 & $34^{\circ} 16^{\prime} \mathrm{S}$ & $18^{\circ} 23^{\prime} \mathrm{E}$ \\
\hline $89 / 11 / 1$ & 304 & $\mathbf{F}$ & - & SA & $S$ & 5 Apr. 1989 & $32^{\circ} 46^{\prime} \mathrm{S}$ & $17^{\circ} 59^{\prime} \mathrm{E}$ \\
\hline $89 / 11 / 2$ & 266 & $\mathbf{M}$ & - & $\mathrm{J}$ & $\mathrm{S}$ & 5 Apr. 1989 & $32^{\circ} 46^{\prime} \mathrm{S}$ & $17^{\circ} 59^{\prime} \mathrm{E}$ \\
\hline $89 / 11 / 3$ & 336 & $\mathbf{M}$ & - & A & $\mathrm{S}$ & 5 Apr. 1989 & $32^{\circ} 46^{\prime} \mathrm{S}$ & $17^{\circ} 59^{\prime} \mathrm{E}$ \\
\hline $89 / 11 / 4$ & 276 & M & - & $J$ & $S$ & 5 Apr. 1989 & $32^{\circ} 46^{\prime} \mathrm{S}$ & $17^{\circ} 59^{\prime} \mathrm{E}$ \\
\hline $89 / 11 / 5$ & 270 & $\mathbf{F}$ & - & $J$ & $\mathrm{~S}$ & 5 Apr. 1989 & $32^{\circ} 46^{\prime} \mathrm{S}$ & $17^{\circ} 59^{\prime} \mathrm{E}$ \\
\hline $89 / 11 / 6$ & 286 & M & - & $\mathrm{J}$ & $\mathrm{S}$ & 5 Apr. 1989 & $32^{\circ} 46^{\prime} \mathrm{S}$ & $17^{\circ} 59^{\prime} \mathrm{E}$ \\
\hline $89 / 11 / 8$ & 306 & $M$ & - & SA & $\mathrm{S}$ & 5 Apr. 1989 & $32^{\circ} 46^{\prime} \mathrm{S}$ & $17^{\circ} 59^{\prime} \mathrm{E}$ \\
\hline $89 / 11 / 9$ & 282 & $\mathrm{~F}$ & - & $\mathrm{SA}$ & S & 5 Apr. 1989 & $32^{\circ} 46^{\prime} \mathrm{S}$ & $17^{\circ} 59^{\prime} \mathrm{E}$ \\
\hline $89 / 20$ & 294 & $\mathrm{~F}$ & - & SA & $\mathrm{s}$ & 17 Jun. 1989 & $34^{\circ} 18^{\prime} \mathrm{S}$ & $18^{\circ} 28^{\prime} \mathrm{E}$ \\
\hline $89 / 22$ & 281 & $F$ & 324 & SA & $\mathrm{S}$ & 17 Jul. 1989 & $34^{\circ} 12^{\prime} \mathrm{S}$ & $18^{\circ} 27^{\prime} \mathrm{E}$ \\
\hline $89 / 35$ & 226 & $\mathbf{M}$ & 96 & $\mathbf{J}$ & $S$ & 23 Feb. 1989 & $34^{\circ} 22^{\prime} \mathrm{S}$ & $20^{\circ} 52^{\prime} \mathrm{E}$ \\
\hline $90 / 27$ & 305 & M & 318 & SA & $\mathrm{S}$ & 3 Apr. 1990 & $34^{\circ} 50^{\prime} \mathrm{S}$ & $20^{\circ} 01^{\prime} \mathrm{E}$ \\
\hline
\end{tabular}




\begin{tabular}{|c|c|c|c|c|c|c|c|c|}
\hline Field no. & Length(cm) & Sex & Weight(kg) & Age & Origin & Date & \multicolumn{2}{|c|}{ Location } \\
\hline \multicolumn{9}{|c|}{ Bottlenose dolphin } \\
\hline $80 / 25$ & 266 & $\mathrm{M}$ & 260 & $\mathrm{~J}$ & $\mathrm{~S}$ & 17 Oct. 1980 & $22^{\circ} 50^{\prime} \mathrm{S}$ & $14^{\circ} 31^{\prime} \mathrm{E}$ \\
\hline $82 / 12$ & 275 & $M$ & 169 & A & $\mathrm{S}$ & 15 Jun. 1982 & $33^{\circ} 25^{\prime} \mathrm{S}$ & $19^{\circ} 08^{\prime} \mathrm{E}$ \\
\hline $83 / 45$ & 293 & $\mathbf{M}$ & 265 & SA & $\mathrm{S}$ & 21 Dec. 1983 & $34^{\circ} 29^{\prime} \mathrm{S}$ & $19^{\circ} 21^{\prime} \mathrm{E}$ \\
\hline $89 / 08$ & 259 & M & 166 & SA & $\mathrm{S}$ & 28 Dec. 1988 & $34^{\circ} 22^{\prime} \mathrm{S}$ & $20^{\circ} 52^{\prime} \mathrm{E}$ \\
\hline $89 / 17$ & 293 & $\mathbf{F}$ & 204 & A & $\mathbf{S}$ & 3 Jun. 1989 & $34^{\circ} 22^{\prime} \mathrm{S}$ & $18^{\circ} 50^{\prime} \mathrm{E}$ \\
\hline $89 / 18$ & 218 & $\mathbf{F}$ & - & $\mathrm{C}$ & $\mathrm{S}$ & 3 Jun. 1989 & $34^{\circ} 22{ }^{\prime} \mathrm{S}$ & $18^{\circ} 50^{\prime} \mathrm{E}$ \\
\hline $83 / 28 / 1$ & 281 & $\mathbf{F}$ & 304 & A & $\mathrm{S}$ & 14 Jun. 1983 & $32^{\circ} 43^{\prime} \mathrm{S}$ & $17^{\circ} 56^{\prime} \mathrm{E}$ \\
\hline $83 / 28 / 2$ & 220 & $\mathbf{F}$ & 125 & $\mathrm{C}$ & $S$ & 14 Jun. 1983 & $32^{\circ} 43^{\prime} \mathrm{S}$ & $17^{\circ} 56^{\prime} \mathrm{E}$ \\
\hline $83 / 29$ & 227 & $\mathbf{M}$ & 130 & $\mathrm{~J}$ & $\mathrm{~S}$ & 15 Jun. 1983 & $34^{\circ} 11^{\prime} \mathrm{S}$ & $22^{\circ} 09^{\prime} \mathrm{E}$ \\
\hline $84 / 13$ & 135 & $M$ & 26 & $\mathrm{C}$ & $\mathbf{S}$ & 14 Mar. 1984 & $22^{\circ} 13^{\prime} \mathrm{S}$ & $14^{\circ} 19^{\prime} \mathrm{E}$ \\
\hline $85 / 14$ & 172 & $\mathbf{M}$ & 60 & $\mathrm{~J}$ & $\mathrm{~s}$ & 24 May 1985 & $34^{\circ} 08^{\prime} \mathrm{S}$ & $18^{\circ} 20^{\prime} \mathrm{E}$ \\
\hline $85 / 19$ & - & $\mathrm{M}$ & - & $\mathrm{C}$ & $\mathrm{s}$ & 12 Dec. 1985 & $34^{\prime \prime} 13^{\prime} \mathrm{S}$ & $22^{\circ} 02^{\prime} \mathrm{E}$ \\
\hline \multicolumn{9}{|c|}{ Striped dolphin } \\
\hline $82 / 14$ & 195 & $\mathbf{M}$ & 62 & $\mathbf{J}$ & $\mathrm{S}$ & 7 Jul. 1982 & $34^{\circ} 22^{\prime} \mathrm{S}$ & $21^{\circ} 26^{\prime} \mathrm{E}$ \\
\hline $83 / 42$ & 215 & $\mathbf{F}$ & 96 & SA & $\mathrm{S}$ & 6 Dec. 1983 & $34^{\circ} 09^{\prime} \mathrm{S}$ & $18^{\circ} 51^{\prime} \mathrm{E}$ \\
\hline $84 / 31$ & 230 & $\mathbf{F}$ & 116 & A & $\mathrm{s}$ & 18 Oct. 1984 & $34^{\circ} 08^{\prime} \mathrm{S}$ & $18^{\circ} 20^{\prime} \mathrm{E}$ \\
\hline $87 / 37$ & 199 & M & 77 & $\mathbf{J}$ & $\mathrm{s}$ & 19 Dec. 1987 & $34^{\circ} 23^{\prime} \mathrm{S}$ & $21^{\circ} 12^{\prime} \mathrm{E}$ \\
\hline $89 / 28$ & 216 & $\mathrm{M}$ & 104 & SA & $\mathrm{s}$ & 28 Nov. 1989 & $34^{\circ} 33^{\prime} \mathrm{S}$ & $20^{\circ} 25^{\prime} \mathrm{E}$ \\
\hline \multicolumn{9}{|c|}{ Pantropical spotted dolphin } \\
\hline $84 / 19$ & 210 & $\mathbf{F}$ & 88 & SA & $\mathrm{s}$ & 25 Jun. 1984 & $34^{\circ} 40^{\prime} \mathrm{S}$ & $19^{\circ} 29^{\prime} \mathrm{E}$ \\
\hline \multicolumn{9}{|c|}{ Humpback dolphin } \\
\hline $90 / 35$ & 259 & $\mathrm{~F}$ & 171 & A & $\mathrm{S}$ & 24 Nov. 1990 & $34^{\circ} 22^{\prime} \mathrm{S}$ & $21^{\circ} 26^{\prime} \mathrm{E}$ \\
\hline \multicolumn{9}{|c|}{ Dusky dolphin } \\
\hline $82 / 01$ & 165 & M & 52 & SA & $\mathrm{S}$ & 6 Jan. 1982 & $22^{\circ} 50^{\prime} \mathrm{S}$ & $14^{\circ} 31^{\prime} \mathrm{E}$ \\
\hline $83 / 32$ & - & $\mathbf{F}$ & - & A & $\mathrm{s}$ & 16 Jul. 1983 & $33^{\circ} 54^{\prime} \mathrm{S}$ & $18^{\circ} 24^{\prime} \mathrm{E}$ \\
\hline $83 / 38$ & 187 & $\mathrm{M}$ & 86 & SA & $\mathbf{P}$ & 22 Nov. 1983 & $33^{\circ} 22^{\prime} \mathrm{S}$ & $18^{\circ} 00^{\prime} \mathrm{E}$ \\
\hline $84 / 10$ & 166 & M & 68 & SA & $P$ & 26 Feb. 1984 & $32^{\circ} 16^{\prime} \mathrm{S}$ & $18^{\circ} 13^{\prime} \mathrm{E}$ \\
\hline $84 / 33$ & 169 & $\mathrm{~F}$ & 62 & $\mathbf{J}$ & $\mathrm{S}$ & 6 Jan. 1982 & $22 " 57 \mathrm{~S}$ & $14^{\circ} 30^{\prime} \mathrm{E}$ \\
\hline $86 / 03$ & 89 & M & 8 & C & $\mathrm{s}$ & 22 Jan. 1986 & $34^{\circ} 08^{\prime} \mathrm{S}$ & $18^{\circ} 27^{\prime} \mathrm{E}$ \\
\hline $86 / 24$ & 187 & $\mathrm{~F}$ & 93 & A & I & 16 May 1986 & $32^{\circ} 43^{\prime} \mathrm{S}$ & $17^{\prime \prime} 58^{\prime} \mathrm{E}$ \\
\hline $87 / 01$ & 178 & $\mathbf{F}$ & 55 & SA & $\mathrm{s}$ & 7 Feb. 1987 & $34 " 12$ 's & $18^{\circ} 22^{\prime} \mathrm{E}$ \\
\hline $87 / 03$ & 92 & M & 9 & $\mathrm{C}$ & $\mathrm{s}$ & 25 Feb. 1987 & $33^{\circ} 43^{\prime} \mathrm{S}$ & $18^{\circ} 27^{\prime} \mathrm{E}$ \\
\hline $88 / 15$ & 160 & M & 59 & $\mathrm{~J}$ & I & 13 Jul. 1988 & $19^{\circ} 20^{\prime} \mathrm{S}$ & $12^{\prime \prime} 32^{\prime} \mathrm{E}$ \\
\hline $88 / 16$ & 182 & $F$ & 78 & SA & $\mathbf{I}$ & 13 Jul. 1988 & $19^{\circ} 20^{\prime} \mathrm{S}$ & $12^{\prime \prime} 32^{\prime} \mathrm{E}$ \\
\hline $88 / 17$ & 173 & $\mathbf{F}$ & 65 & $\mathrm{~J}$ & I & 13 Jul. 1988 & $19^{\circ} 20^{\prime} \mathrm{S}$ & $12^{\prime \prime} 32^{\prime} \mathrm{E}$ \\
\hline $88 / 18$ & 176 & $\mathbf{F}$ & 78 & SA & I & 13 Jul. 1988 & $19^{\circ} 20^{\prime} \mathrm{S}$ & $12^{\prime \prime} 32^{\prime} \mathrm{E}$ \\
\hline $89 / 09$ & 167 & $\mathbf{F}$ & 57 & $\mathrm{~J}$ & I & 19 Mar. 1989 & $34^{\circ} 08^{\prime} \mathrm{S}$ & $18^{\circ} 27^{\prime} \mathrm{E}$ \\
\hline $89 / 26$ & 173 & $\mathbf{F}$ & 67 & SA & I & 26 Oct. 1989 & $30^{\circ} 00^{\prime} \mathrm{S}$ & $16^{\circ} 0 l^{\prime} \mathrm{E}$ \\
\hline $89 / 27$ & 176 & $\mathbf{F}$ & 66 & $\mathrm{~J}$ & I & 26 Oct. 1989 & $30^{\circ} 00^{\prime} \mathrm{S}$ & $16^{\circ} 01^{\prime} \mathrm{E}$ \\
\hline $89 / 31$ & 170 & $\mathbf{F}$ & 69 & $\mathrm{~J}$ & I & 23 Jun. 1989 & $24 " 44$ 'S & $14^{\circ} 28^{\prime} \mathrm{E}$ \\
\hline $89 / 32$ & 176 & $\mathbf{F}$ & 62 & $\mathrm{~J}$ & I & 27 Jun. 1989 & $18^{\circ} I 5^{\prime} S$ & $12^{\prime \prime} 04^{\prime} \mathrm{E}$ \\
\hline $89 / 33$ & 169 & $\mathbf{F}$ & 64 & $\mathrm{~J}$ & I & 23 Jun. 1989 & $24 " 4.45$ & $14^{\prime \prime} 28^{\prime} \mathrm{E}$ \\
\hline $89 / 34$ & 156 & $\mathrm{M}$ & 56 & $\mathrm{~J}$ & I & 23 Jun. 1989 & $24 " 44$ 's & $14^{\circ} 28^{\prime} \mathrm{E}$ \\
\hline $90 / 23$ & 170 & F & 68 & $\mathrm{~J}$ & I & 11 May 1990 & $30^{\circ} 49^{\prime} \mathrm{S}$ & $17^{\circ} 29^{\prime} \mathrm{E}$ \\
\hline \multicolumn{9}{|c|}{ Hourglass dolphin } \\
\hline $82 / 07$ & 164 & $\mathrm{~F}$ & 74 & $\mathrm{~J}$ & $\mathrm{P}$ & 25 Dec. 1981 & $55^{\prime \prime} 39^{\prime} \mathrm{S}$ & $60^{\circ} 41^{\prime} \mathrm{W}$ \\
\hline \multicolumn{9}{|c|}{ Heaviside's dolphin } \\
\hline $77 / 07$ & 168 & $\mathrm{~F}$ & 64 & A & $\mathrm{P}$ & 18 Jan. 1977 & $23^{\circ} 00^{\prime} \mathrm{S}$ & $1 t^{\prime \prime} 22^{\prime} \mathrm{E}$ \\
\hline $80 / 17$ & 166 & $\mathrm{~F}$ & 68 & $\mathrm{SA}$ & $\mathrm{P}$ & 24 Aug. 1980 & $29^{\prime \prime} 08^{\prime} \mathrm{S}$ & $16^{\circ} 46^{\prime} \mathrm{E}$ \\
\hline $82 / 19$ & 158 & $\mathbf{F}$ & 52 & $\mathrm{~J}$ & $P$ & 28 Aug. 1982 & $30^{\circ} 52$ 's & $17^{\circ} 33^{\prime} \mathrm{E}$ \\
\hline $84 / 08$ & 147 & M & 51 & $\mathrm{~J}$ & $\mathrm{P}$ & $26 \mathrm{Feb} .1984$ & $32^{\circ} 50^{\prime} \mathrm{S}$ & $17^{\circ} 45^{\prime} \mathrm{E}$ \\
\hline $84 / 09$ & 156 & M & 56 & $\mathrm{SA}$ & $P$ & 28 Aug. 1982 & $32^{\circ} 45^{\prime} \mathrm{S}$ & $17^{\prime \prime} 46^{\prime} \mathrm{E}$ \\
\hline $84 / 30$ & 156 & $M$ & 59 & $\mathrm{~A}$ & $\mathrm{P}$ & 29 Sep. 1984 & $30^{\circ} 25^{\prime} \mathrm{S}$ & $17^{\circ} 18^{\prime} \mathrm{E}$ \\
\hline $85 / 07$ & 118 & $\mathrm{~F}$ & 27 & $\mathrm{~J}$ & $\mathrm{~S}$ & 9 Apr. 1985 & $32^{\prime \prime 2} 20 \mathrm{~s}$ & $18^{\circ} 19^{\prime} \mathrm{E}$ \\
\hline
\end{tabular}




\begin{tabular}{|c|c|c|c|c|c|c|c|c|}
\hline Field no. & Length $(\mathrm{cm})$ & Sex & Weight(kg) & Age & Origin & Date & \multicolumn{2}{|c|}{ Location } \\
\hline \multicolumn{9}{|c|}{ Heaviside's dolphin (cont.) } \\
\hline $85 / 09$ & - & - & - & SA & I & 11 Mar. 1985 & $32^{\circ} 44^{\prime} \mathrm{S}$ & $17^{\circ} 52^{\prime} \mathrm{E}$ \\
\hline $85 / 15$ & 151 & M & 44 & $\mathrm{SA}$ & $\mathbf{S}$ & 19 Jul. 1985 & $34^{\circ} 03^{\prime} \mathrm{S}$ & $18^{\circ} 22^{\prime} \mathrm{E}$ \\
\hline $87 / 15$ & 155 & $\mathbf{M}$ & 46 & J & P & 17 Aug. 1987 & $18^{\circ} 48^{\prime} \mathrm{S}$ & $12^{\circ} 19^{\prime} \mathrm{E}$ \\
\hline $89 / 29$ & 79 & M & 6 & $\mathrm{C}$ & S & 18 Jan. 1989 & $22^{\circ} 07^{\prime} \mathrm{S}$ & $14^{\circ} 16^{\prime} \mathrm{E}$ \\
\hline $90 / 21$ & 164 & $\mathbf{M}$ & 68 & SA & I & 19 Apr. 1990 & $30^{\circ} 18^{\prime} \mathrm{S}$ & $17^{\circ} 10^{\prime} \mathrm{E}$ \\
\hline \multicolumn{9}{|c|}{ Common dolphin } \\
\hline $82 / 06$ & 102 & $\mathbf{M}$ & 10 & $\mathrm{C}$ & $\mathrm{s}$ & 15 Feb. 1982 & $34^{\circ} 10^{\prime} \mathrm{S}$ & $18^{\circ} 26^{\prime} \mathrm{E}$ \\
\hline $83 / 01$ & 224 & M & 136 & SA & $\mathbf{P}$ & 23 Jan. 1983 & $34^{\circ} 38^{\prime} \mathrm{S}$ & $24^{\circ} 38^{\prime} \mathrm{E}$ \\
\hline $83 / 02$ & 208 & $F$ & 87 & $\mathbf{J}$ & $P$ & 26 Jan. 1983 & $33^{\circ} 50^{\prime} \mathrm{S}$ & $25^{\circ} 50^{\prime} \mathrm{E}$ \\
\hline $83 / 03$ & 221 & $F$ & 136 & $\mathrm{SA}$ & $\mathbf{P}$ & 27 Jan. 1983 & $34^{\circ} 15^{\prime} \mathrm{S}$ & $24^{\circ} 53^{\prime} \mathrm{E}$ \\
\hline $83 / 04$ & 196 & M & 85 & $\mathbf{J}$ & $\mathbf{P}$ & 9 Feb. 1983 & $34^{\circ} 18^{\prime} \mathrm{S}$ & $18^{\circ} 18^{\prime} \mathrm{E}$ \\
\hline $83 / 05$ & 203 & $\mathrm{~F}$ & 88 & $\mathrm{~J}$ & $P$ & 12 Feb. 1983 & $34^{\circ} 44^{\prime} \mathrm{S}$ & $19^{\circ} 04^{\prime} \mathrm{E}$ \\
\hline $83 / 06$ & 220 & $F$ & 103 & $\mathrm{~J}$ & $\mathrm{P}$ & 13 Feb. 1983 & $34^{\circ} 49^{\prime} \mathrm{S}$ & $20^{\circ} 29^{\prime} \mathrm{E}$ \\
\hline $83 / 10$ & 248 & M & 158 & A & $\mathrm{s}$ & 5 Mar. 1983 & $34^{\prime \prime} 28 ' \mathrm{~S}$ & $20^{\circ} 32^{\prime} \mathrm{E}$ \\
\hline $83 / 11$ & 190 & $\mathbf{M}$ & 76 & $\mathrm{~J}$ & I & 23 Feb. 1983 & $17^{\circ} 42^{\prime} \mathrm{S}$ & $11^{\circ} 28^{\prime} \mathrm{E}$ \\
\hline $83 / 12$ & 177 & $F$ & 65 & $\mathrm{~J}$ & I & 22 Feb. 1983 & $17^{\circ} 45^{\prime} \mathrm{S}$ & $11^{\circ} 26^{\prime} \mathrm{E}$ \\
\hline $83 / 19$ & 215 & M & 81 & J & S & 1 Apr. 1983 & $34^{\circ} 19^{\prime} \mathrm{S}$ & $18^{\circ} 28^{\prime} \mathrm{E}$ \\
\hline $83 / 36$ & 208 & $F$ & 96 & J & I & 8 Nov. 1983 & $34^{\circ} 28 ' \mathrm{~S}$ & $20^{\circ} 58^{\prime} \mathrm{E}$ \\
\hline $83 / 37$ & 215 & $\mathbf{F}$ & 90 & $\mathbf{J}$ & I & 8 Nov. 1983 & $34^{\circ} 28^{\prime} \mathrm{S}$ & $20^{\circ} 58^{\prime} \mathrm{E}$ \\
\hline $83 / 39$ & 223 & $\mathbf{M}$ & 109 & $\mathrm{SA}$ & $P$ & 29 Nov, 1983 & $34^{\circ} 14^{\prime} \mathrm{S}$ & $18^{\circ} 19^{\prime} \mathrm{E}$ \\
\hline $83 / 40$ & 210 & $F$ & 90 & $\mathbf{J}$ & $P$ & 29 Nov. 1983 & $34^{\circ} 27^{\prime} \mathrm{S}$ & $18^{\circ} 29^{\prime} \mathrm{E}$ \\
\hline $84 / 01$ & 208 & M & 82 & $\mathbf{J}$ & $S$ & 26 Jan. 1984 & $34^{\circ} 08^{\prime} \mathrm{S}$ & $18^{\circ} 20^{\prime} \mathrm{E}$ \\
\hline $84 / 03$ & 222 & $\mathbf{M}$ & 106 & $J$ & $P$ & 22 Feb. 1984 & $34^{\circ} 48^{\prime} \mathrm{S}$ & $19^{\circ} 11^{\prime} \mathrm{E}$ \\
\hline $84 / 04$ & 232 & $\mathbf{M}$ & 121 & SA & $\mathbf{P}$ & 22 Feb. 1984 & $34^{\circ} 54^{\prime} \mathrm{S}$ & $19^{\circ} 31^{\prime} \mathrm{E}$ \\
\hline $84 / 05$ & 230 & $\mathbf{M}$ & 115 & $\mathrm{SA}$ & $\mathbf{P}$ & 22 Feb. 1984 & $35^{\circ} 00^{\prime} \mathrm{S}$ & $19^{\circ} 58^{\prime} \mathrm{E}$ \\
\hline $84 / 06$ & 210 & $\mathbf{M}$ & 102 & $\mathbf{J}$ & $\mathbf{P}$ & 24 Feb. 1984 & $34^{\circ} 44^{\prime} \mathrm{S}$ & $19^{\circ} 04^{\prime} \mathrm{E}$ \\
\hline $84 / 07$ & 215 & $\mathbf{F}$ & 98 & $\mathrm{~J}$ & $\mathbf{P}$ & 24 Feb. 1984 & $34^{\circ} 39^{\prime} \mathrm{S}$ & $18^{\circ} 59^{\prime} \mathrm{E}$ \\
\hline $84 / 17$ & 149 & $\mathbf{M}$ & 27 & $J$ & $\mathrm{~S}$ & 30 Apr. 1984 & $34^{\circ} 22^{\prime} \mathrm{S}$ & $18^{\circ} 52^{\prime} \mathrm{E}$ \\
\hline $84 / 32$ & 155 & $\mathbf{M}$ & 38 & $\mathrm{~J}$ & $S$ & 30 Nov. 1984 & $34^{\circ} 26^{\prime} \mathrm{S}$ & $19^{\circ} 14^{\prime} \mathrm{E}$ \\
\hline $85 / 11$ & 216 & $\mathrm{~F}$ & 92 & $\mathrm{~J}$ & $P$ & 18 Apr. 1985 & $34^{\circ} 07^{\prime} \mathrm{S}$ & $22^{\circ} 3 \mathrm{I}^{\prime} \mathrm{E}$ \\
\hline $85 / 12$ & 210 & $\mathbf{M}$ & 93 & $\mathrm{~J}$ & $P$ & 21 Apr. 1985 & $34^{\circ} 00^{\prime} \mathrm{S}$ & $25^{\circ} 08^{\prime} \mathrm{E}$ \\
\hline $85 / 13$ & 254 & $\mathbf{M}$ & 158 & SA & $P$ & 24 Apr. 1985 & $34^{\circ} 27^{\prime} \mathrm{S}$ & $21^{\circ} 34^{\prime} \mathrm{E}$ \\
\hline $86 / 01$ & 195 & $\mathrm{~F}$ & 80 & SA & $\mathrm{S}$ & 3 Jan. 1986 & $34^{\circ} 39^{\prime} \mathrm{S}$ & $20^{\circ} 15^{\prime} \mathrm{E}$ \\
\hline $86 / 07$ & 115 & M & 15 & $\mathbf{J}$ & $\mathrm{s}$ & 10 Feb. 1986 & $34^{\circ} 05^{\prime} \mathrm{S}$ & $18^{\circ} 34^{\prime} \mathrm{E}$ \\
\hline $86 / 09$ & 220 & $F$ & 100 & SA & I & 18 Feb. 1986 & $34^{\circ} 35^{\prime} \mathrm{S}$ & $19^{\circ} 05^{\prime} \mathrm{E}$ \\
\hline $86 / 10$ & 207 & M & 84 & $\mathrm{~J}$ & I & 18 Feb. 1986 & $34^{\circ} 35^{\prime} \mathrm{S}$ & $19^{\circ} 05^{\prime} \mathrm{E}$ \\
\hline $86 / 11$ & 197 & $\mathbf{M}$ & 69 & $\mathbf{J}$ & I & 18 Feb. 1986 & $34^{\circ} 35^{\prime} \mathrm{S}$ & $19^{\circ} 05^{\prime} \mathrm{E}$ \\
\hline $86 / 12$ & 211 & $F$ & 84 & $\mathbf{J}$ & I & 18 Feb. 1986 & $34^{\circ} 35^{\prime} \mathrm{S}$ & $19^{\circ} 05^{\prime} \mathrm{E}$ \\
\hline $86 / 13$ & 226 & $\mathrm{~F}$ & 98 & $\mathbf{J}$ & I & 18 Feb. 1986 & $34^{\circ} 35^{\prime} \mathrm{S}$ & $19^{\circ} 05^{\prime} \mathrm{E}$ \\
\hline $86 / 33$ & 207 & $\mathbf{M}$ & 65 & $J$ & S & 6 Sep. 1986 & $34^{\circ} 09^{\prime} \mathrm{S}$ & $18^{\circ} 27^{\prime} \mathrm{E}$ \\
\hline $86 / 37$ & 224 & M & 124 & SA & $\mathrm{S}$ & 24 Oct. 1986 & $34^{\circ} 06^{\prime} \mathrm{S}$ & $18^{\circ} 31^{\prime} \mathrm{E}$ \\
\hline $86 / 39$ & 243 & $\mathbf{M}$ & 129 & $\mathrm{~A}$ & $\mathrm{~S}$ & 10 Oct. 1986 & $34^{\circ} 45 ' \mathrm{~S}$ & $19^{\circ} 36^{\prime} \mathrm{E}$ \\
\hline $87 / 07$ & 184 & $\mathbf{F}$ & 63 & $\mathbf{J}$ & $\mathrm{S}$ & 10 Mar. 1987 & $34^{\circ} 24^{\prime} \mathrm{S}$ & $19^{\circ} 16^{\prime} \mathrm{E}$ \\
\hline $87 / 36$ & 217 & $\mathbf{F}$ & 96 & SA & $\mathrm{S}$ & 17 Dec. 1987 & $34^{\circ} 23^{\prime} \mathrm{S}$ & $21^{\circ} 12^{\prime} \mathrm{E}$ \\
\hline $89 / 25$ & 165 & $\mathbf{F}$ & 34 & $\mathbf{J}$ & $\mathbf{S}$ & 15 Sep. 1989 & $33^{\circ} 54^{\prime} \mathrm{S}$ & $18^{\circ} 28^{\prime} \mathrm{E}$ \\
\hline $90 / 01$ & 224 & $\mathbf{F}$ & 96 & A & $\mathrm{S}$ & 6 Jan. 1990 & $34^{\circ} 06^{\prime} \mathrm{S}$ & $18^{\circ} 48^{\prime} \mathrm{E}$ \\
\hline $90 / 22$ & 224 & $\mathrm{~F}$ & 94 & SA & $\mathbf{S}$ & $25 \mathrm{Apr} .1990$ & $34^{\circ} 43^{\prime} \mathrm{S}$ & $20^{\circ} 07^{\prime} \mathrm{E}$ \\
\hline $90 / 24$ & 151 & $\mathbf{F}$ & 31 & $J$ & - & - & - & - \\
\hline $90 / 31$ & 231 & $\mathrm{~F}$ & 94 & A & S & 4 Sep. 1990 & $34^{\circ} 47^{\prime} \mathrm{S}$ & $19^{\circ} 38^{\prime} \mathrm{E}$ \\
\hline
\end{tabular}




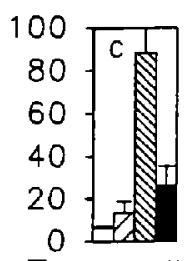

E. australis

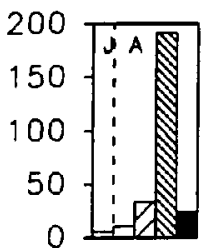

C. marginata

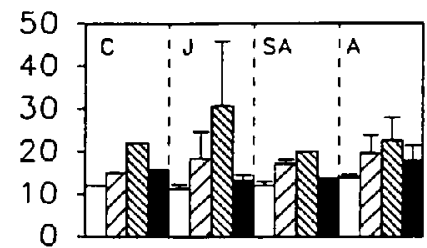

K. breviceps

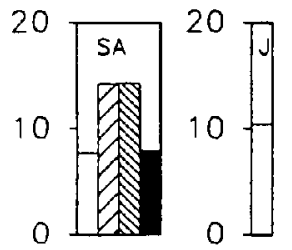

H. planifrons

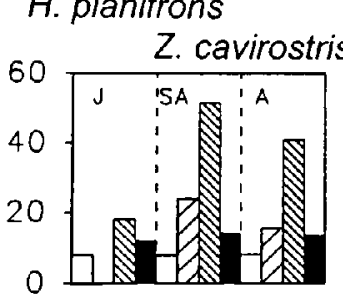

G. melas

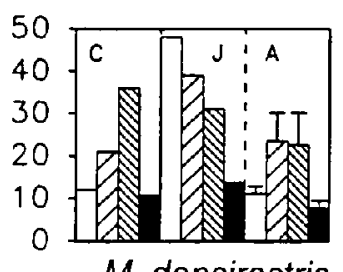

M. densirostris

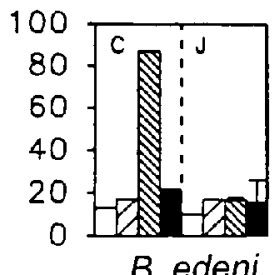

B. edeni

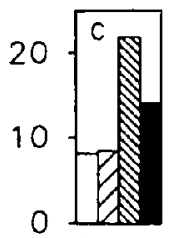

M.novaeangliae

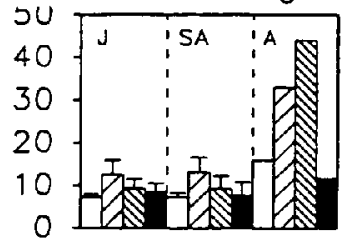

K. simus

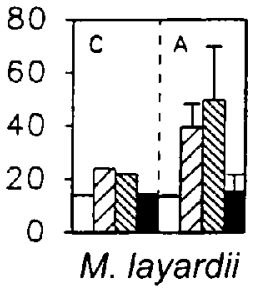

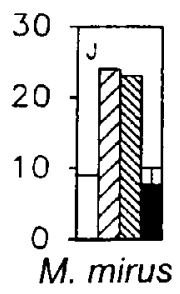

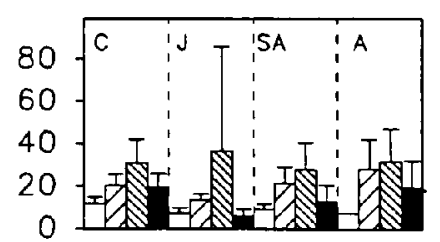

G. griseus

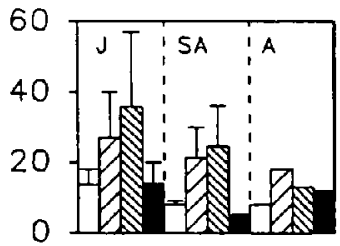

S. coeruleoalba

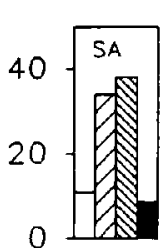

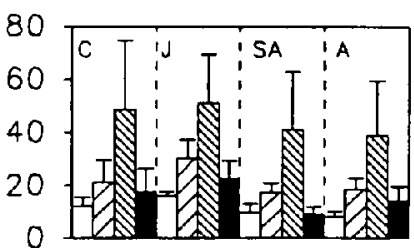

$T$. truncatus

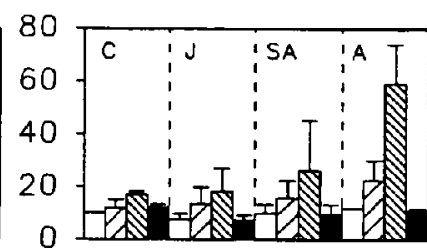

L. obscurus

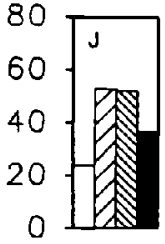

L. cruciger
S. attenuata

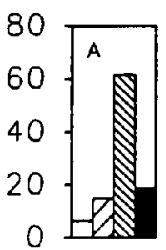

S. plumbea

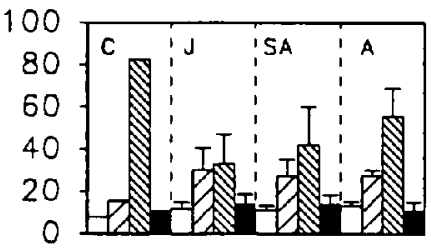

C. heavisidii

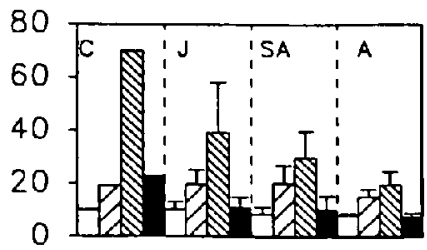

D. delphis

Appendix Fig. 1. Mean concentrations (in $\mu \mathrm{g} / \mathrm{g}$ wet weight) of zinc in brain (open), kidney (rising right), liver (rising left) and muscle (solid) of different age classes of cetaceans from southem $A f r i c a(C=c a l f$, $\mathrm{J}=$ juvenile, $\mathrm{SA}=$ sub-adult, $\mathrm{A}=$ adult . 


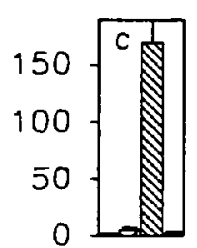

E. australis

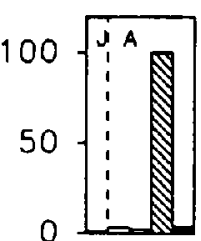

C. marginata

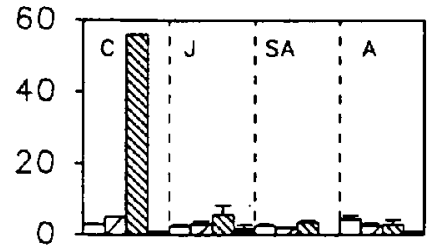

K. breviceps

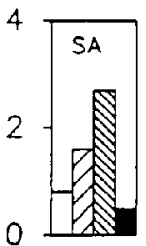

H. planifrons

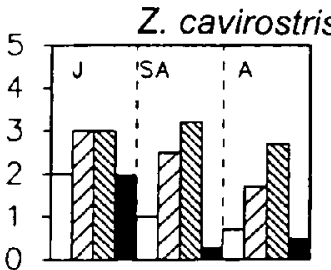

G. melas

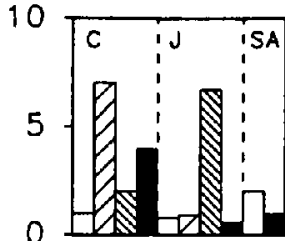

B. acutorostrata
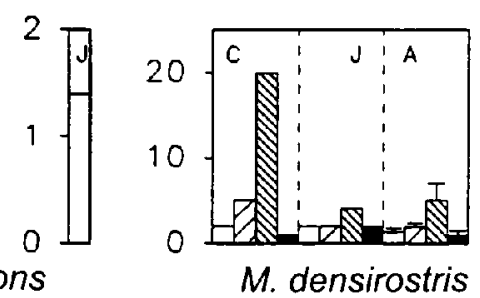

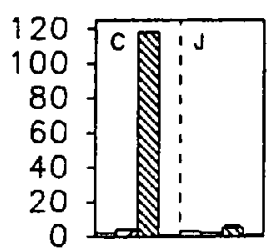

B. edeni

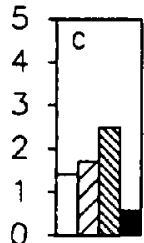

M. novaeangliae

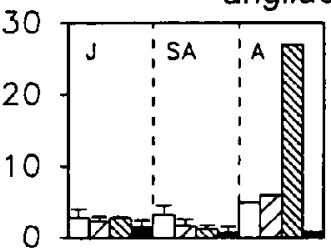

K. simus
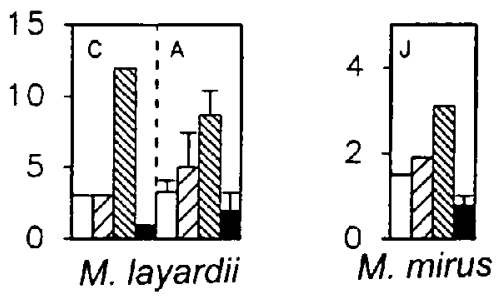

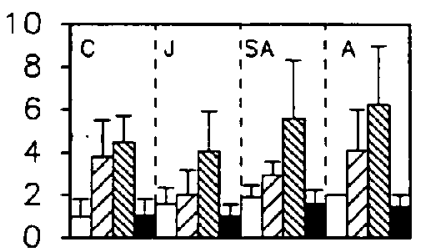

G. griseus

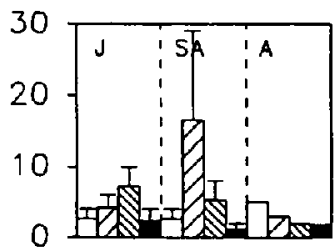

S. coeruleoalba

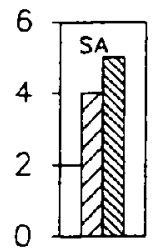

S. attenuata

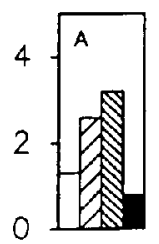

S. plumbea

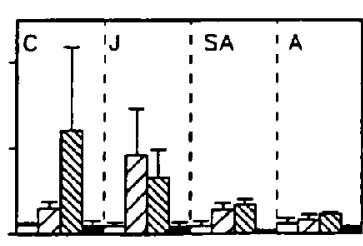

$T$. truncatus

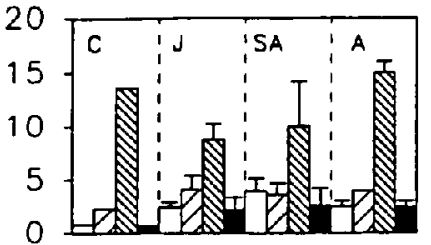

C. heavisidii

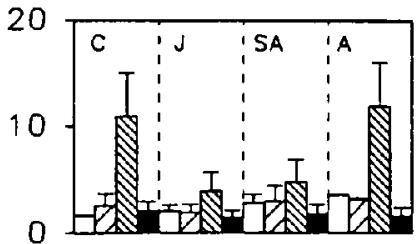

L. obscurus

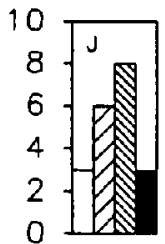

L. cruciger

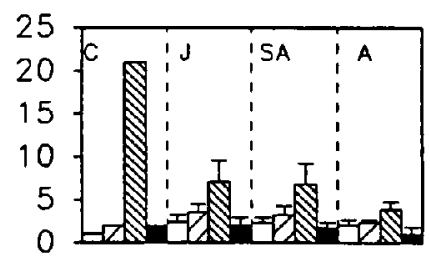

D. delphis

Appendix Fig. 2. Mean concentrations (in $\mu \mathrm{g} / \mathrm{g}$ wet weight) of copper in brain (open), kidney (rising right), liver (rising left) and muscle (solid) of different age classes of cetaceans from southern Africa $(\mathrm{C}=$ calf, $\mathrm{J}=$ juvenile, $\mathrm{SA}=$ sub-adult, $\mathrm{A}=$ adult $)$. 

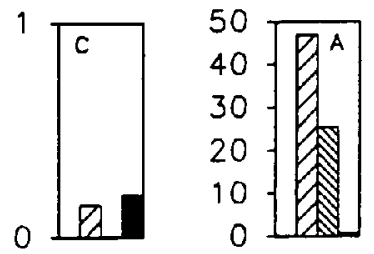

E. australis

C. marginata

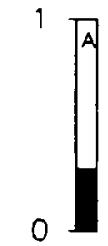

P. macrocephalus

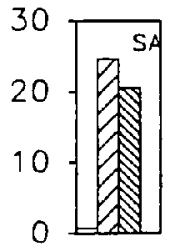

H. planifrons

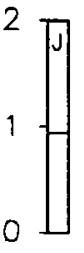

Z. cavirostris

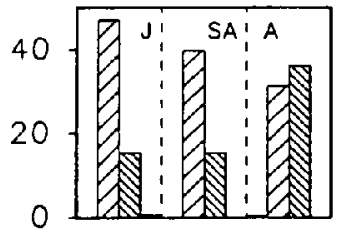

G. melas
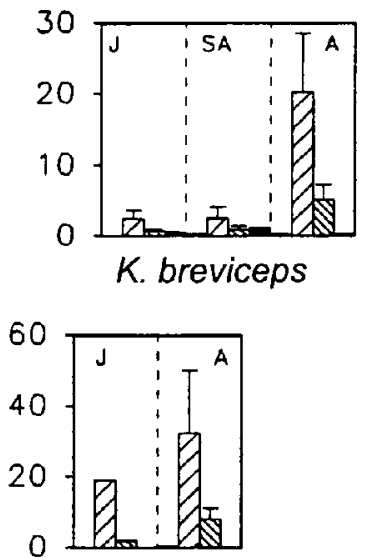

M. densirostris

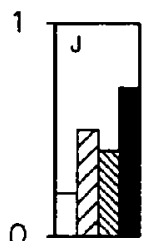

B. edeni

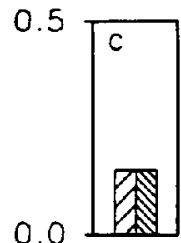

M.novaeangliae

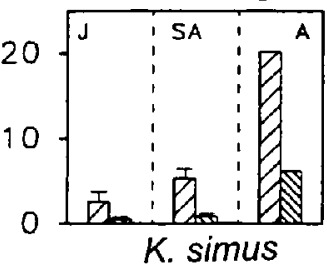

K. simus

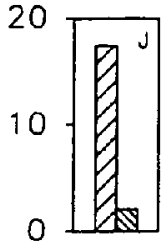

M. mirus

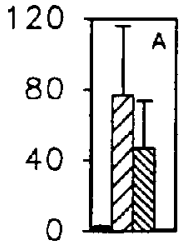

M. layardii

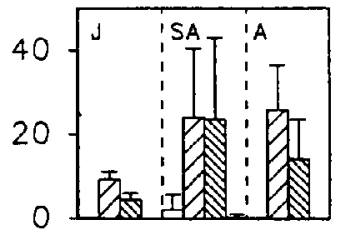

G. griseus

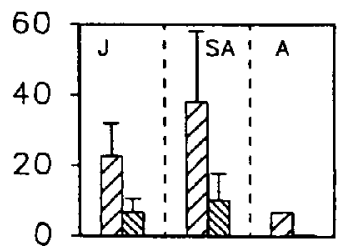

S. coeruleoalba

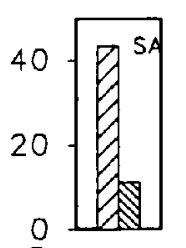

S. attenuata

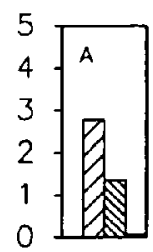

S.plumbea

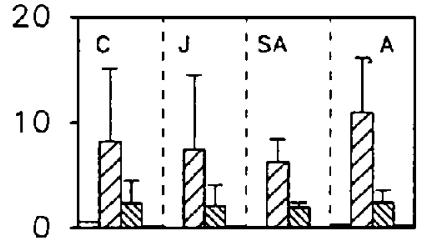

$T$. truncatus

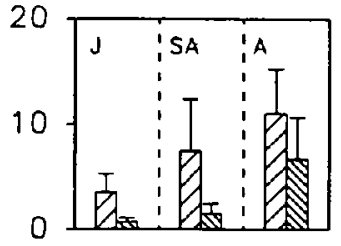

L. obscurus

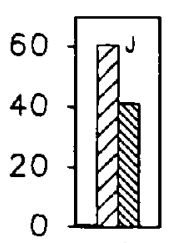

L. cruciger

Appendix Fig. 3. Mean concentrations (in $\mu \mathrm{g} / \mathrm{g}$ wet weight) of cadmium in brain (open), kidney (rising right), liver (rising left) and muscle (solid) of different age classes of cetaceans from southern Africa $(C=$ calf, $\mathrm{J}=$ juvenile, $\mathrm{SA}=$ sub-adult, $\mathrm{A}=$ adult $)$. 


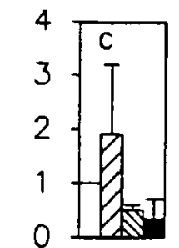

E. australis

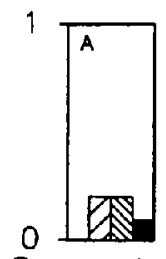

C. marginata
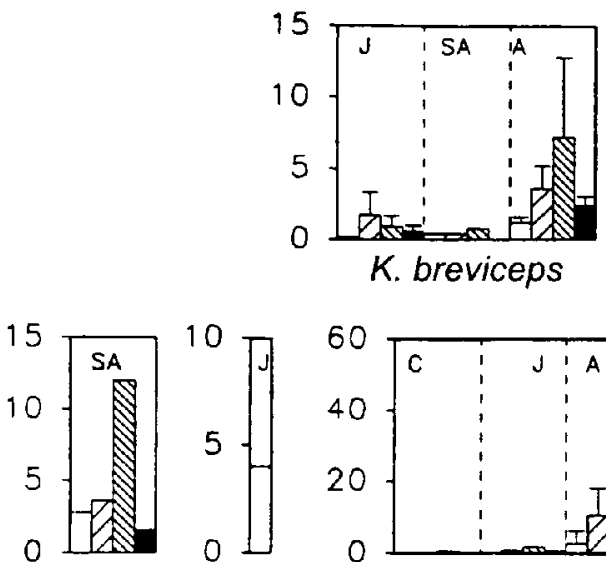

$H$. planifrons Z. cavirostris

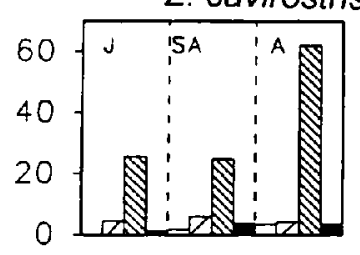

G. melas

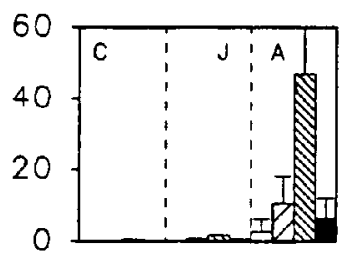

M. densirostris

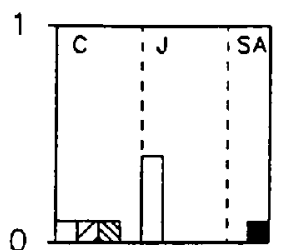

B. acutorostrata

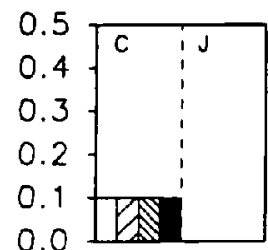

B. edeni

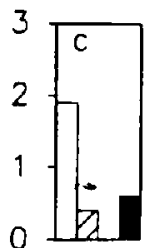

M.novaeangliae

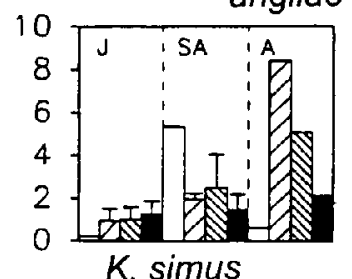

K. simus
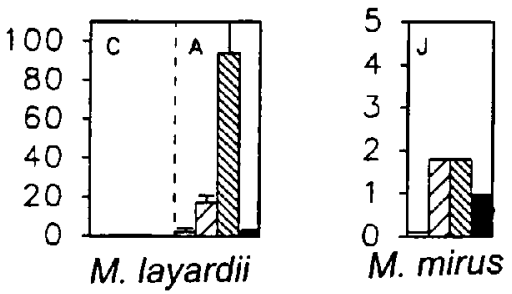

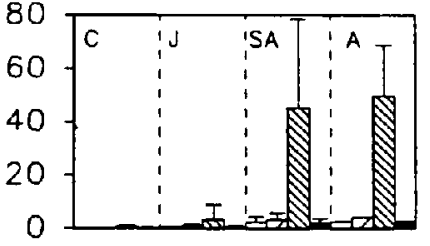

G. griseus

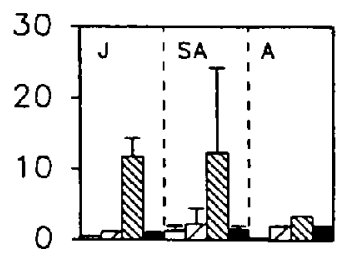

S. coeruleoalba

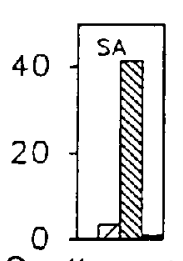

$S$. attenuata

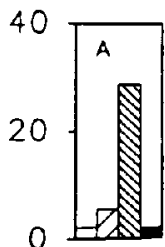

S. plumbea

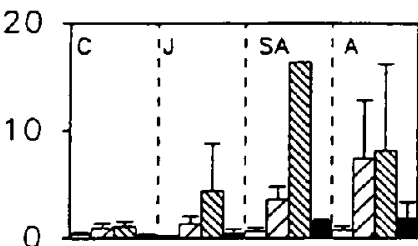

T. truncatus

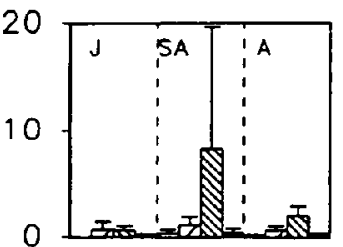

C. heavisidii

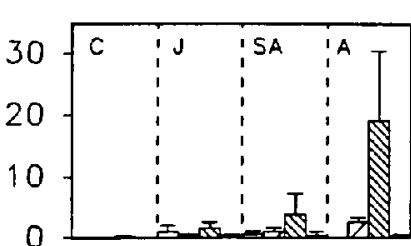

L. obscurus

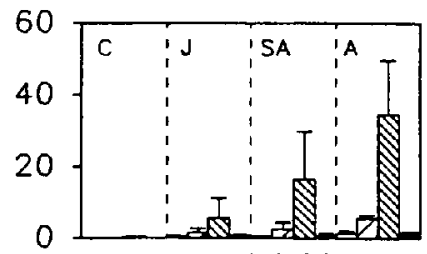

D. delphis

Appendix Fig. 4. Mean concentrations (in $\mu \mathrm{g} / \mathrm{g}$ wet weight) of mercury in brain (open), kidney (rising right), liver (rising left) and muscle (solid) of different age classes of cetaceans from southern Africa $(C=$ calf, $\mathrm{J}=$ juvenile, $\mathrm{SA}=$ sub-adult, $\mathrm{A}=$ adult $)$. 


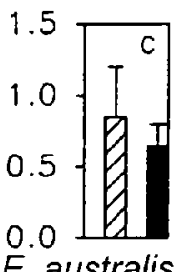

E. australis

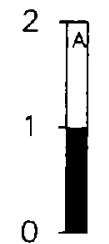

P. macrocephalus

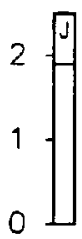

Z. cavirostris

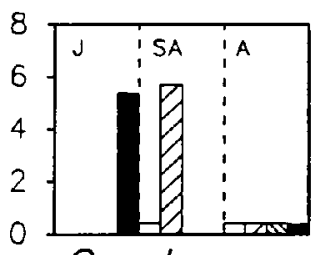

G. melas

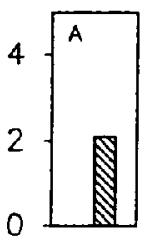

C. marginata

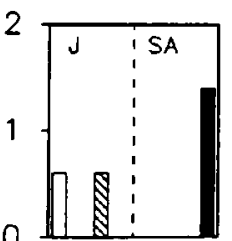

B. acutorostrata

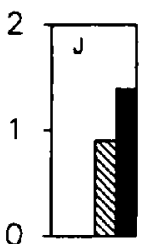

B. edeni

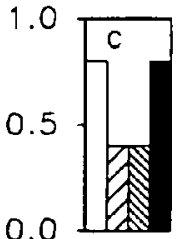

M.novae-

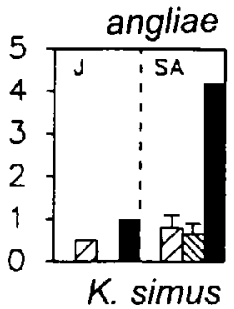

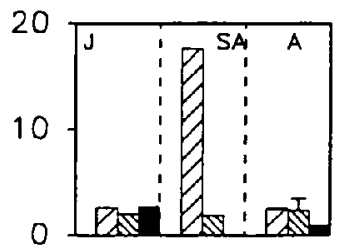

K. breviceps

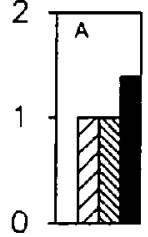

M. densirostris

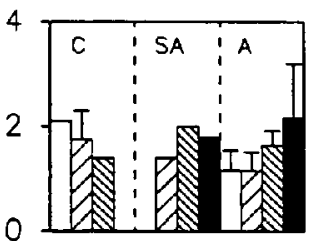

G. griseus

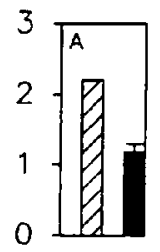

M. layardii

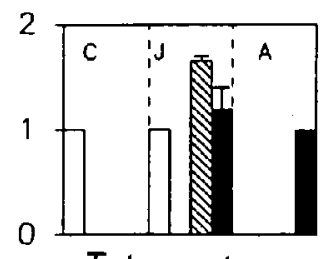

T. truncatus

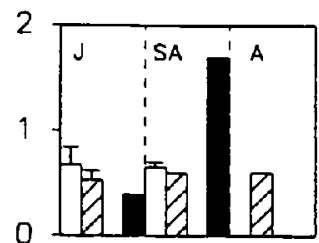

L. obscurus

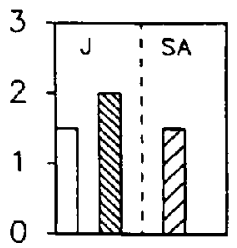

S. coeruleoalba
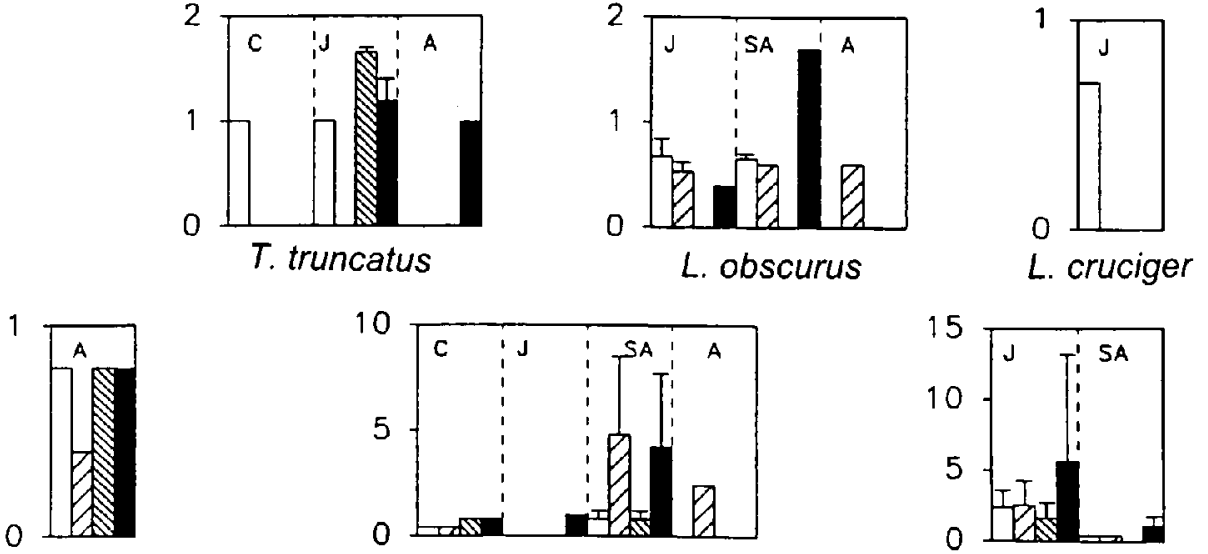

S. plumbea

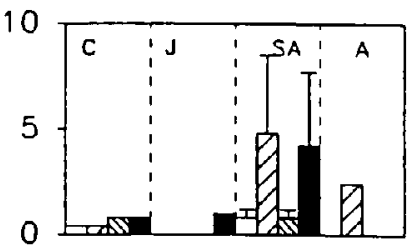

C. heavisidii

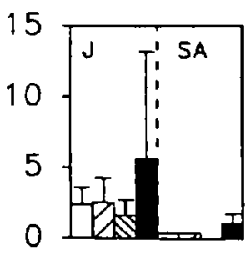

D. delphis

Appendix Fig. 5. Mean concentrations (in $\mu \mathrm{g} / \mathrm{g}$ wet weight) of lead in brain (open), kidney (rising right), liver (rising left) and muscle (solid) of different age classes of celaceans from southem $A$ frica $(C=$ calf, $\mathrm{J}=$ juvenile, $\mathrm{SA}=$ sub-adult $\mathrm{A}=$ adult). 